\title{
Article \\ Genome-Wide Identification and Evolution of Receptor-Like Kinases (RLKs) and Receptor like Proteins (RLPs) in Brassica juncea
}

\author{
Hua Yang ${ }^{1,2}$, Philipp E. Bayer ${ }^{1}$, Soodeh Tirnaz ${ }^{1}$, David Edwards ${ }^{1}$ (D) and Jacqueline Batley ${ }^{1, * \mathbb{C}}$ \\ 1 School of Biological Sciences, University of Western Australia, Crawley, WA 6009, Australia; \\ hua.yang1@uq.net.au (H.Y.); Philipp.bayer@uwa.edu.au (P.E.B.); soodeh.tirnaz@research.uwa.edu.au (S.T.); \\ Dave.edwards@uwa.edu.au (D.E.) \\ 2 School of Agriculture and Food Sciences, University of Queensland, St Lucia, QLD 4067, Australia \\ * Correspondence: Jacqueline.batley@uwa.edu.au; Tel.: +61-8-6488-5929
}

Citation: Yang, H.; Bayer, P.E.; Tirnaz, S.; Edwards, D.; Batley, J. Genome-Wide Identification and Evolution of Receptor-Like Kinases (RLKs) and Receptor like Proteins (RLPs) in Brassica juncea. Biology 2021, 10, 17. https://doi.org/10.3390/ biology10010017

Received: 27 October 2020 Accepted: 21 December 2020 Published: 30 December 2020

Publisher's Note: MDPI stays neutral with regard to jurisdictional clai$\mathrm{ms}$ in published maps and institutional affiliations.

Copyright: () 2020 by the authors. Licensee MDPI, Basel, Switzerland. This article is an open access article distributed under the terms and conditions of the Creative Commons Attribution (CC BY) license (https:// creativecommons.org/licenses/by/ $4.0 /)$.
Simple Summary: Plants have evolved defence mechanisms to protect themselves against microbial pathogens. The identification of genes underlying quantitative trait loci is extremely challenging in complex polyploid genomes. In this research, we identify and characterise two types of resistance genes; RLKs (receptor like kinases) and RLPs (receptor like proteins) in Indian mustard (Brassica juncea), one of the major crops in India and an important member of the Brassicaceae family, which can be linked to QTL for disease resistance. The outcome provides a valuable resource for facilitating the identification of functional resistance genes which can be employed by breeders toward the production of resistant cultivars.

\begin{abstract}
Brassica juncea, an allotetraploid species, is an important germplasm resource for canola improvement, due to its many beneficial agronomic traits, such as heat and drought tolerance and blackleg resistance. Receptor-like kinase (RLK) and receptor-like protein (RLP) genes are two types of resistance gene analogues (RGA) that play important roles in plant innate immunity, stress response and various development processes. In this study, genome wide analysis of RLKs and RLPs is performed in B. juncea. In total, 493 RLKs (LysM-RLKs and LRR-RLKs) and 228 RLPs (LysM-RLPs and LRR-RLPs) are identified in the genome of B. juncea, using RGAugury. Only $13.54 \%$ RLKs and $11.79 \%$ RLPs are observed to be grouped within gene clusters. The majority of RLKs (90.17\%) and RLPs (52.83\%) are identified as duplicates, indicating that gene duplications significantly contribute to the expansion of RLK and RLP families. Comparative analysis between B. juncea and its progenitor species, B. rapa and B. nigra, indicate that $83.62 \%$ RLKs and $41.98 \%$ RLPs are conserved in $B$. juncea, and RLPs are likely to have a faster evolution than RLKs. This study provides a valuable resource for the identification and characterisation of candidate RLK and RLP genes.
\end{abstract}

Keywords: receptor-like kinases (RLK); receptor-like proteins (RLP); disease resistance; Indian mustard; Brassica juncea; resistance genes

\section{Introduction}

In plants, cell surface receptors play an important role in perceiving self-derived or non-self-derived extracellular signals, where the communication between the extracellular matrix and the cell interior happens [1,2]. Plant receptor-like kinases (RLKs) and receptorlike proteins (RLPs) constitute two major classes of cell-surface receptors. Generally, the plant cell surface receptors participate in innate immunity, stress responses and a wide variety of developmental processes [3-9]. A typical structure of RLKs is composed of a single-pass transmembrane domain and a cytoplasmic kinase domain $[10,11]$. RLPs are structurally similar to RLKs. The only difference is that the RLP carries a short cytoplasmic tail instead of the intracellular kinase domain present in RLKs $[9,12]$. Due to the kinase 
domain, the RLKs can trigger signalling on their own, whereas RLPs require the formation of a functional complex with an RLK to activate downstream signalling [13-15]. The first RLP was identified in Solanum lycopersicum; defined as $C f-9$, a leucine-rich repeat RLP (LRRRLP), which confers resistance to the effector Avr9 of the fungus Cladosporium fulvum [16]. Whereas, the first report of a RLK, ZmPK1, was isolated from Zea mays, and belongs to the S-domain class, functioning in specific self-pollen recognition [17].

RLKs and RLPs can be classified into sub-families on the basis of the type of extracellular domain they carry. The largest subfamily of RLK and RLP families carry a leucine-rich repeat (LRR) domain and are defined as LRR-RLK and LRR-RLP [3,4]. These two subfamilies, LRR-RLKs and LRR-RLPs, are known to participate widely in plant defence and development. In plants, both LRR-RLKs and LRR-RLPs have been observed to contain significant rates of duplication, loss or retention [10,12,18-22].

Further sub-families of RLKs and RLPs carry the Lysin motif (LysnM) and are known as LysM-RLK and LysM-RLP. These sub-families of proteins play an important role in innate immunity and/or symbiosis. In Arabidopsis thaliana, the LysM-containing chitin elicitor RLK1 (CERK1) has been found to be essential for chitin perception and also functions in defence response against fungal pathogens [23-26]. In contrast, LysM-RLKs in legumes coordinate with rhizobial bacteria to control symbiotic processes, through perceiving secreted bacterial lipochitooligosaccharides (Nod factor, NF) signals [27-31].

Brassica juncea, commonly known as Indian mustard, is an allotetraploid plant species with $\mathrm{AABB}$ genome produced by natural interspecific hybridisation between the diploid species $B$. nigra (BB) and B. rapa (AA) [32,33]. It is widely planted, as it is known to contain many beneficial agronomic traits compared to $B$. napus, such as increased heat and drought tolerance, high blackleg and shatter resistance and early vigour [34-40]. The B. juncea reference genome, $922 \mathrm{Mb}$ in length, is currently available [33]. This provides an opportunity to characterise the LRR-RLK and LRR-RLP genes in B. juncea and understand their genomic distribution.

Whilst a genome-wide study of the evolution and distribution of nucleotide binding site-leucine-rich repeat (NLR) resistance genes have been conducted in B. juncea [41], the majority of RLK (LysM-RLK and LRR-RLK) and RLP (LysM-RLP and LRR-RLP) genes remain uncharacterised in $B$. juncea. Here, we present the identification, characterisation and distribution of the RLKs and RLPs subfamilies in the B. juncea genome. Comparative analyses are also performed to identify the orthologous genes and define collinear relationships between B. juncea and its related diploid progenitors, B. rapa and B. nigra. The outcomes provide information that facilitate the further investigation of resistance gene evolution and distribution in $B$. juncea, which ultimately can assist breeders for resistance improvement.

\section{Materials and Methods}

\subsection{Brassica Reference Genomes}

The Brassica genomes used in this study, include B. juncea T84-66 v1.5 (genome: AABB, $779.5 \mathrm{Mbp}$ ) [33], B. nigra DH YZ12151 scaffold version (genome: BB) [33] and B. rapa Chiifu401-42 v2.5 (genome: AA, 370.2 Mbp) [42]. Their genome sequence, annotation and protein sequences were obtained from the website http://brassicadb.org/brad/.

\subsection{Genome Wide Identification of RLK and RLP Genes}

Candidate proteins of RLK and RLP families were retrieved using the RGAugury pipeline [43]. Firstly, BLASTp analysis was performed to screen potential RGA candidates in Brassica species against the database RGAdb with an E-value cut-off of $\mathrm{E}^{-5}$. Secondly, specific domains in RLKs (LRR, LysM, TM and STTK domains) and RLPs (LRR, LysM and TM domains) were detected through InterProScan and Phobius. Finally, the genes were classified into RLKs and RLPs on the basis of their unique domain structures. Brassica RLKs were grouped into three-types: LRR-RLK, LysM-RLK and RLK-other-receptor; while RLPs 
contained two types, namely LRR-RLP and LysM-RLP. In this study, we focused on LysM and LRR types of RLKs and RLPs.

\subsection{Genomic Distribution of RLK and RLP Genes}

RLKs and RLPs were mapped to their corresponding chromosomes on the basis of their physical positions in the Brassica genomes. Gene clusters were determined using the physical positions of the genes which were situated on the same chromosome. In this study, a gene cluster was defined as a chromosome region harbouring three or more genes within $200 \mathrm{~kb}$, according to previous literature [44]. Clusters formed by tandem duplications were defined as a tandem cluster. RLK and RLP clusters were detected, according to the kinase domain.

\subsection{Gene Duplication Analysis of RLK and RLP Genes}

Gene duplication analysis in this study was performed on the basis of previously reported criteria, with over $70 \%$ in both the coverage and identity of alignment during BLASTp comparison [45-47]. Gene duplicates located within a $5 \mathrm{Mb}$ region on the same chromosome were considered as tandemly duplicated, while those situated beyond $5 \mathrm{Mb}$ were defined as segmentally duplicated [48-50]. The duplication events observed within the B. juncea A or B sub-genomes were defined as intra-genomic duplications. In contrast, inter-genomic duplications referred to the duplications between the A and B sub-genomes.

\subsection{Ortholog and Paralog Analysis}

Paralogous copies were defined as the duplicated genes which occupied two different positions in the same genome [51,52]. Paralogous genes were confirmed by the BLASTp comparison of all the predicted RLKs and RLPs proteins against each other with E-value of E-20 [45]. However, orthologous genes, which were observed in two different species originating from a common ancestor, were confirmed when the E-value was smaller than E-45 during BLASTp comparison of all the predicted RLK or RLP proteins against each other, with over $70 \%$ of similarity and coverage [51,52].

\subsection{Multiple Alignment and Phylogenetic Analysis}

Multiple sequence alignment of RLK and RLP proteins were performed separately in Geneious v7.1.9 with the CLUSTAL W method (Biomatters, Auckland, New Zealand) [53]. The neighbour-joining method with 1000 bootstrap iterations was used to construct a phylogenetic tree with aligned proteins in Geneious v7.1.9 (Biomatters, Auckland, New Zealand) [53].

\section{Results}

\subsection{Genome-Wide Identification of RLK and RLP Genes in B. juncea}

A total of 493 candidate RLK genes, accounting for $0.613 \%$ of the predicted coding genes, were identified in the B. juncea genome, which is over twice as many as the RLP family of 228 genes $(0.283 \%)$ (Table 1$)$. Only nine LysM-RLKs and two LysM-RLPs were observed in B. juncea, suggesting that the LysM subfamily was much smaller than the LRR subfamily, which contained 484 LRR-RLKs (98.17\% of RLKs) and 226 LRR-RLPs $(99.12 \%$ of RLPs), respectively (Table 1). 
Table 1. The total number of predicted receptor-like kinase (RLK) and receptor-like protein (RLP) genes identified in the Brassica genomes.

\begin{tabular}{cccc}
\hline Species & B. juncea & B. rapa & B. nigra \\
\hline Gene content & 80,430 & 46,098 & 49,826 \\
RLKs & $493(0.613 \%)$ & $300(0.651 \%)$ & $317(0.636 \%)$ \\
LRR-RLKs & $484(0.602 \%)$ & $297(0.644 \%)$ & $312(0.626 \%)$ \\
LysM-RLKs & $9(0.011 \%)$ & $3(0.007 \%)$ & $5(0.010 \%)$ \\
RLPs & $228(0.283 \%)$ & $65(0.141 \%)$ & $176(0.353 \%)$ \\
LRR-RLPs & $226(0.281 \%)$ & $63(0.137 \%)$ & $175(0.351 \%)$ \\
LysM-RLPs & $2(0.002 \%)$ & $2(0.004 \%)$ & $1(0.002 \%)$ \\
\hline
\end{tabular}

\subsection{Genomic Distribution of RLK and RLP Genes in B. juncea}

Physical mapping was performed to detect the distribution of candidate RLK and RLP genes across the B. juncea genome (Figures 1-4; Tables S1 and S2). In total, 92.90\% of RLKs (458 genes) and $92.98 \%$ of RLPs (212 genes) were physically mapped, according to their corresponding positions in the genome. The remaining genes (35 RLKs and 16 RLPs) could not be assigned to any chromosome in B. juncea.

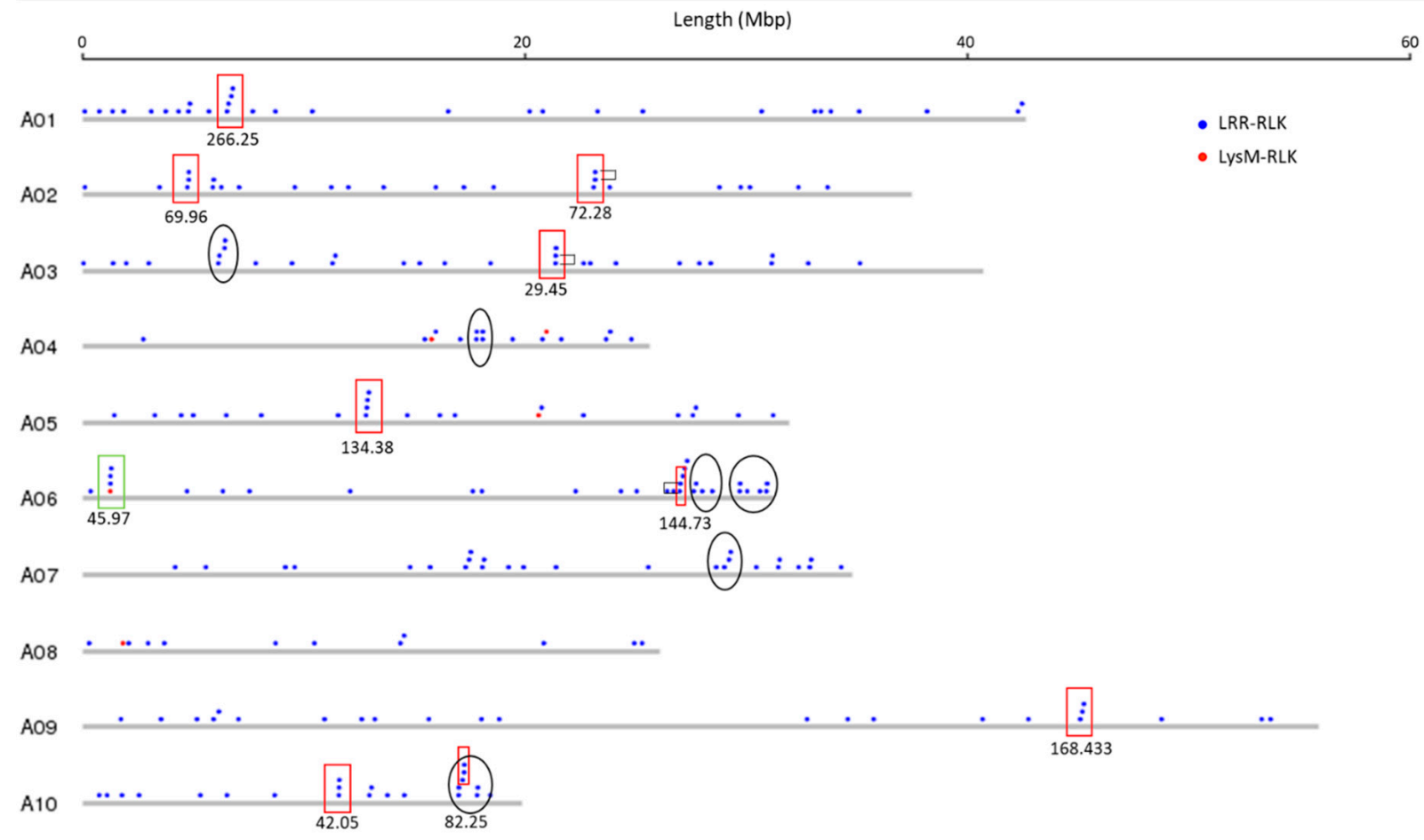

Figure 1. Physical location of receptor-like kinase (RLK) genes (LysM-RLK and LRR-RLK) on the chromosomes of the A genome of $B$. juncea. Solid circles above the chromosome (grey bars) represent RLK genes: LysM-RLK (red) and LRR-RLK (blue). Rectangles represent gene clusters: homogeneous cluster (red) and heterogeneous cluster (green). Numbers below the rectangles indicate the size of gene cluster in $\mathrm{kb}$. Unfilled black ellipses indicate regions rich in RLK genes. Black brackets indicate tandemly-duplicated genes within a gene cluster. Chromosome lengths are displayed in Mbp (megabase pairs) on the scale at top. 


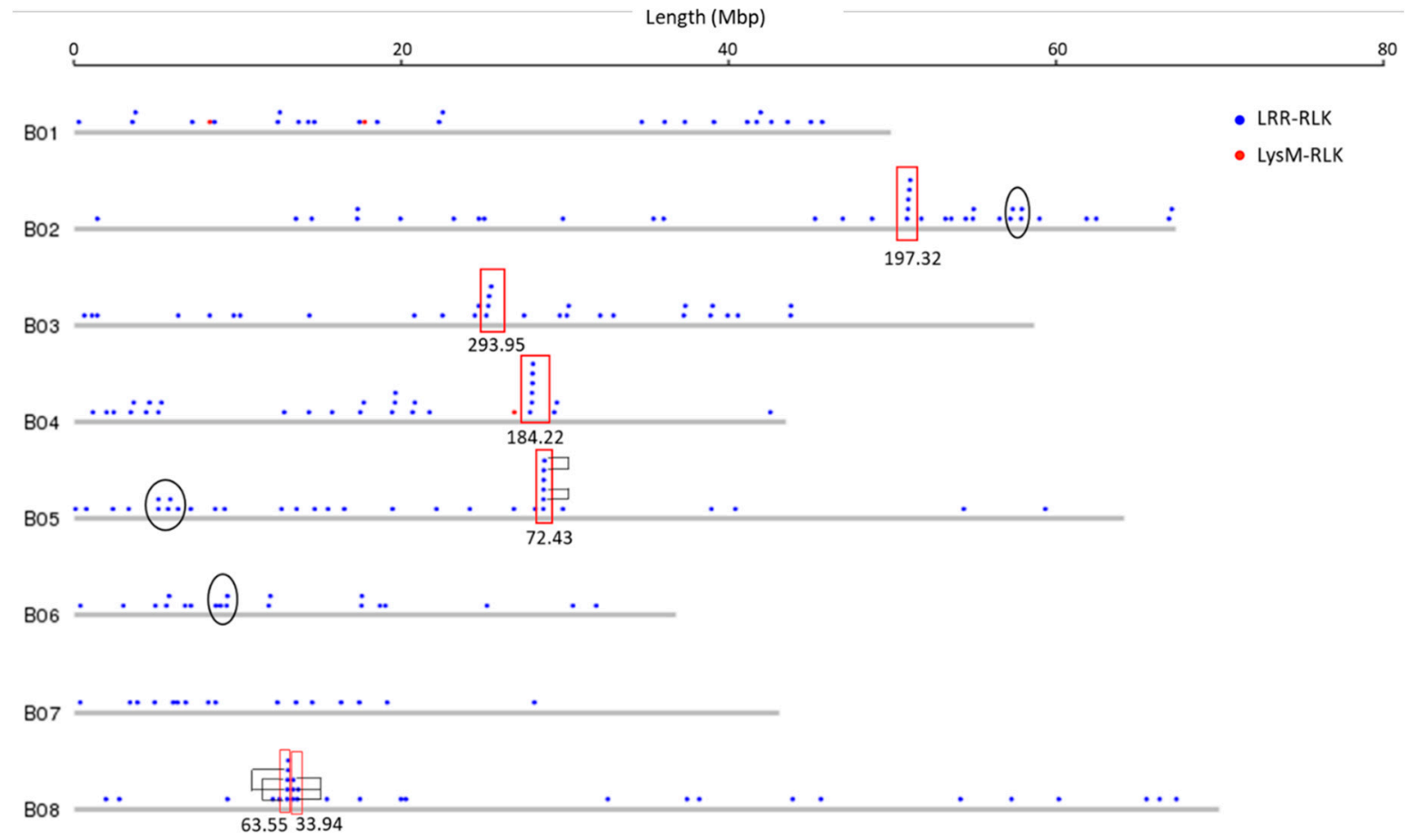

Figure 2. Physical location of RLK genes (LysM-RLK and LRR-RLK) on the chromosomes of the B genome of $B$. juncea. Solid circles above the chromosome (grey bars) represent RLK genes: LysM-RLK (red) and LRR-RLK (blue). Red rectangles represent gene clusters. Numbers below the rectangles indicate the size of gene cluster in $\mathrm{kb}$. Unfilled black ellipses indicate regions rich in RLK genes. Black brackets indicate tandemly-duplicated genes within a gene cluster. Chromosome lengths are displayed in Mbp (megabase pairs) on the scale at top.

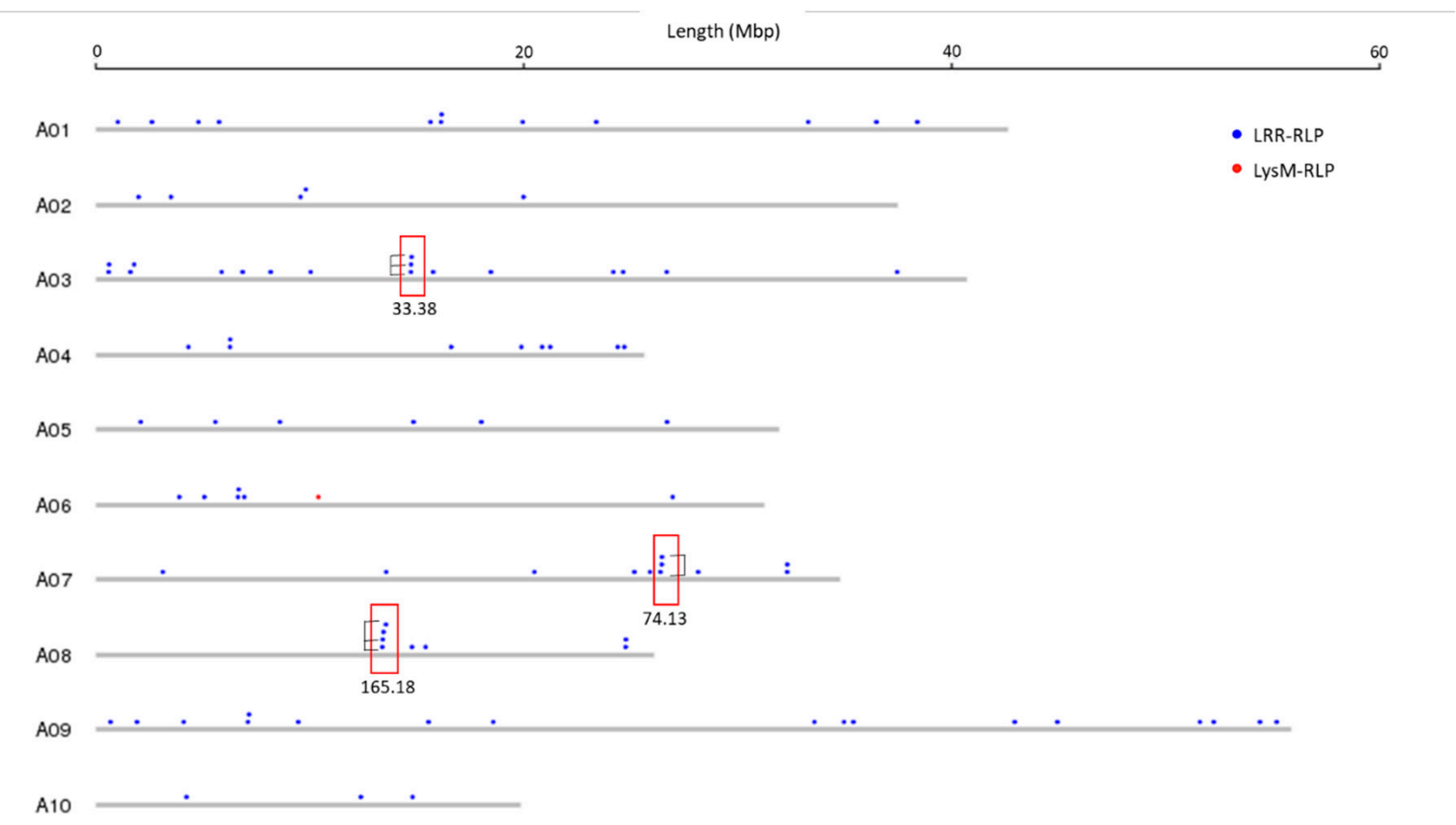

Figure 3. Physical location of receptor-like protein (RLP) genes (LysM-RLP and LRR-RLP) on the chromosomes of the A genome of $B$. juncea. Solid circles above the chromosome (grey bars) represent RLP genes: LysM-RLP (red) and LRR-RLP (blue). Red rectangles represent the gene cluster. Numbers below the rectangles indicate the size of gene cluster in kb. Black brackets indicate tandemly-duplicated genes within a gene cluster. Chromosome lengths are displayed in Mbp on the scale at top. 


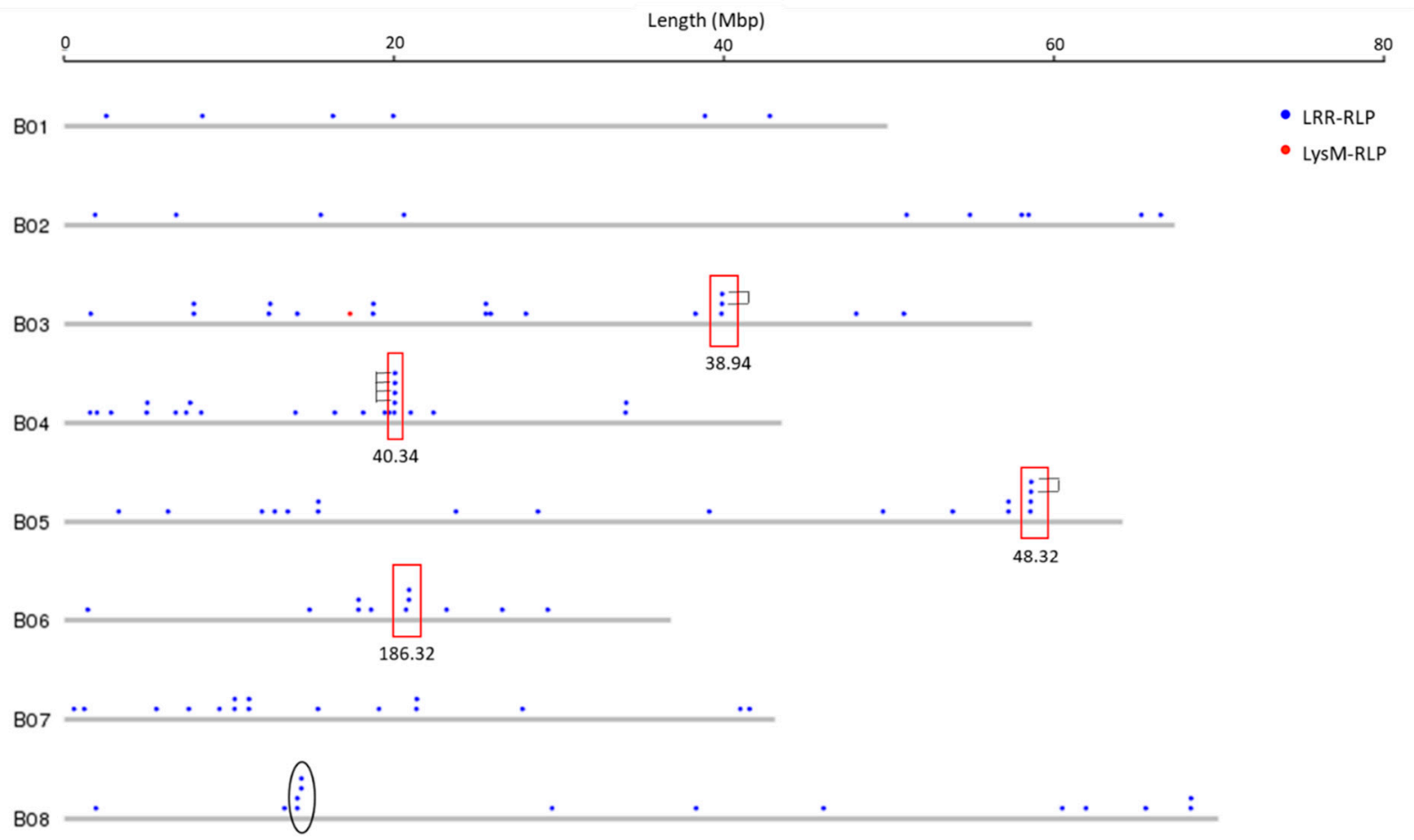

Figure 4. Physical location of RLP genes (LysM-RLP and LRR-RLP) on the chromosomes of the B genome of B. juncea. Solid circles above the chromosome (grey bars) represent RLP genes: LysM-RLP (red) and LRR-RLP (blue). Red rectangles represent the gene cluster. Numbers below the rectangles indicate the size of gene cluster in kb. Unfilled black ellipses indicate regions rich in RLP genes. Black brackets indicate tandemly-duplicated genes within a gene cluster. Chromosome lengths are displayed in Mbp (megabase pairs) on the scale at top. In B. juncea, the mapped RLKs for each chromosome ranged from $2.62 \%$ (12 genes on chromosome A08) to 7.86\% (36 genes on B02) (Table S1). However, $10.85 \%$ (23 genes) of the assigned RLPs were found to be located on chromosome B04, followed by 19 genes (8.96\%) on B03, and the least number were observed on A10 with three genes (1.42\%) (Table S2). In addition, the gene number of both RLKs and RLPs was found to be higher on four chromosomes (B03 to B05, and B08), compared with the other chromosomes (Tables S1 and S2).

In $B$. juncea, the assigned RLKs were distributed almost evenly between the $\mathrm{A}$ and B genomes, with 236 (51.53\%, five LysM-RLKs and 231 LRR-RLKs) and 222 (48.47\%, three LysM-RLKs and 219 LRR-RLKs) (Table S1). The number of RLP genes (117) in the B genome was slightly higher than in the A genome, which contained 95 genes (Table S2). All of the assigned candidate genes were found to be distributed across all the 18 chromosomes in B. juncea (Figures 1-4). LRR-RLKs and LRR-RLPs could be observed on each chromosome, while LysM-RLKs were only present on some chromosomes (A04-A06, A08, B01 and B04). However, only one LysM-RLP was situated on chromosome A06 and B03 (Figures 1-4; Table S2).

\subsection{RLK and RLP Gene Clustering in B. juncea}

In this study, a gene cluster was defined as a chromosomal region harbouring three or more genes within $200 \mathrm{~kb}$. Gene cluster analysis was performed for RLKs and RLPs. Accordingly, 13.54\% (62 genes) of the assigned RLKs were located in gene clusters, while only 25 RLPs (11.79\%) were observed in RLP clusters (Tables S1 and S2). Most of the assigned RLKs and RLPs represented a single-gene locus in B. juncea. In addition, un-clustered RLKs and RLPs were located across the genome of $B$. juncea (Figures 1-4). Some of the un-clustered RLKs and RLPs were closely situated in the chromosomes, forming regions rich in RLKs and RLPs (Figures 1-4).

In total, 16 RLK clusters were observed in the $B$. juncea genome, where 10 of them resided in the A genome, more than in the B genome with six gene clusters (Figures 1 and 2; Table S1). The RLK clusters were almost evenly distributed in the chromosomes of B. juncea, except for on six chromosomes (A04, A07, A08, B01, B06 and B07) (Table S1). However, there 
were only seven RLP gene clusters, which were evenly distributed in seven chromosomes of the B. juncea genome, with three in the A genome, less than in the B genome which had four clusters (Figures 3 and 4; Table S2). All of the RLP clusters were homogeneous, since LysM-RLP genes were not involved in generating gene clusters (Figures 3 and 4; Table S2). By contrast, one LysM-RLK gene, located on chromosome A06, participated in the formation of RLK clusters, resulting in the presence of a heterogeneous cluster (Figures 1 and 2; Table S1).

Most of the large RLK clusters were situated in the B genome chromosomes of B. juncea, where the largest clusters containing six RLKs were found on chromosomes B04 and B05, followed by clusters of five genes on B02 and B08 (Figure 2; Table S1). Additionally, the average gene number of a RLK cluster in the A genome was three genes, smaller than in the B genome with five genes (Table S1). Contrastingly, the highest gene number in a RLP cluster, having five genes, was observed on chromosome B04 (Figures 3 and 4; Table S2). Most of the RLP clusters, which were located on chromosomes A03, A07, B03 and B06, contained three genes (Figures 3 and 4; Table S2).

The size of a cluster was determined by the sequence length between the two RLKs or RLPs situated at both ends of the gene cluster. The size of RLK clusters, with an average of $118.82 \mathrm{~kb}$, ranged from $29.45 \mathrm{~kb}$ on A03 to $293.95 \mathrm{~kb}$ on chromosome B03 (Figures 1 and 2). Similarly, RLP cluster size also ranged from $33.38 \mathrm{~kb}$ to $186.32 \mathrm{kbp}$ on chromosomes A03 and B06, respectively, compared with the average size of $83.80 \mathrm{~kb}$ (Figures 3 and 4). The size of RLK and RLP clusters was not related to the gene number in the cluster (Figures 1-4).

\subsection{Analysis of Duplications and Paralogues of RLK and RLP Genes in B. juncea}

In this study, duplicated genes were detected using BLASTp by comparing all predicted proteins against each other. The RLK and RLP gene families were analysed separately. Duplicated genes, which occupy two different positions in the same genome, were defined as paralogous copies [51,52]. As B. juncea is an allotetraploid species, [32,33], two types of genomic duplications were observed; intra- and inter-genomic duplications (Figure 5; Table 2, Tables S1 and S2). The former is where duplication occurs within the A or B sub-genome of B. juncea. By contrast, the duplication events that occur between the A and B sub-genomes are considered as inter-genomic duplications (Figure 5).

A total of 413 RLKs (90.17\% of the mapped RLKs), consisting of seven LysM-RLKs and 406 LRR-RLKs, were found to be involved in duplication events. Accordingly, 413 paralogous copies were formed in the B. juncea genome (Table S1). A total of $52.83 \%$ of the assigned RLPs were defined as duplications, with 112 genes including two (1.79\%) LysMRLPs and 110 (98.21\%) LRR-RLPs. There were 112 RLP paralogous copies in the B. juncea genome (Table S2). In B. juncea, most of the assigned RLK genes $(90.17 \%)$ had more than one copy, while approximately half of the mapped RLPs (47.17\%) were a single copy.

Table 2. The duplication events defined in the B. juncea genome.

\begin{tabular}{|c|c|c|c|c|c|c|c|c|}
\hline \multirow{3}{*}{ Duplication Type } & \multicolumn{4}{|c|}{ RLK } & \multicolumn{4}{|c|}{ RLP } \\
\hline & \multirow{2}{*}{ Total } & \multicolumn{2}{|c|}{ Intra Sub-Family } & \multirow{2}{*}{$\begin{array}{c}\text { Inter } \\
\text { Sub-Family }\end{array}$} & \multirow{2}{*}{ Total } & \multicolumn{2}{|c|}{ Intra Sub-Family } & \multirow{2}{*}{$\begin{array}{c}\text { Inter } \\
\text { Sub-Family }\end{array}$} \\
\hline & & LysM- & LRR- & & & LysM- & LRR- & \\
\hline Intra A genomic & 83 & 1 & 82 & 0 & 20 & 0 & 20 & 0 \\
\hline Intra B genomic & 80 & 0 & 80 & 0 & 32 & 0 & 32 & 0 \\
\hline $\begin{array}{l}\text { Total of intra } \\
\text { genome }\end{array}$ & 163 & 1 & 162 & 0 & 52 & 0 & 52 & 0 \\
\hline Inter genome & 308 & 4 & 304 & 0 & 58 & 1 & 57 & 0 \\
\hline Total & 471 & 5 & 466 & 0 & 110 & 1 & 109 & 0 \\
\hline
\end{tabular}


(A)

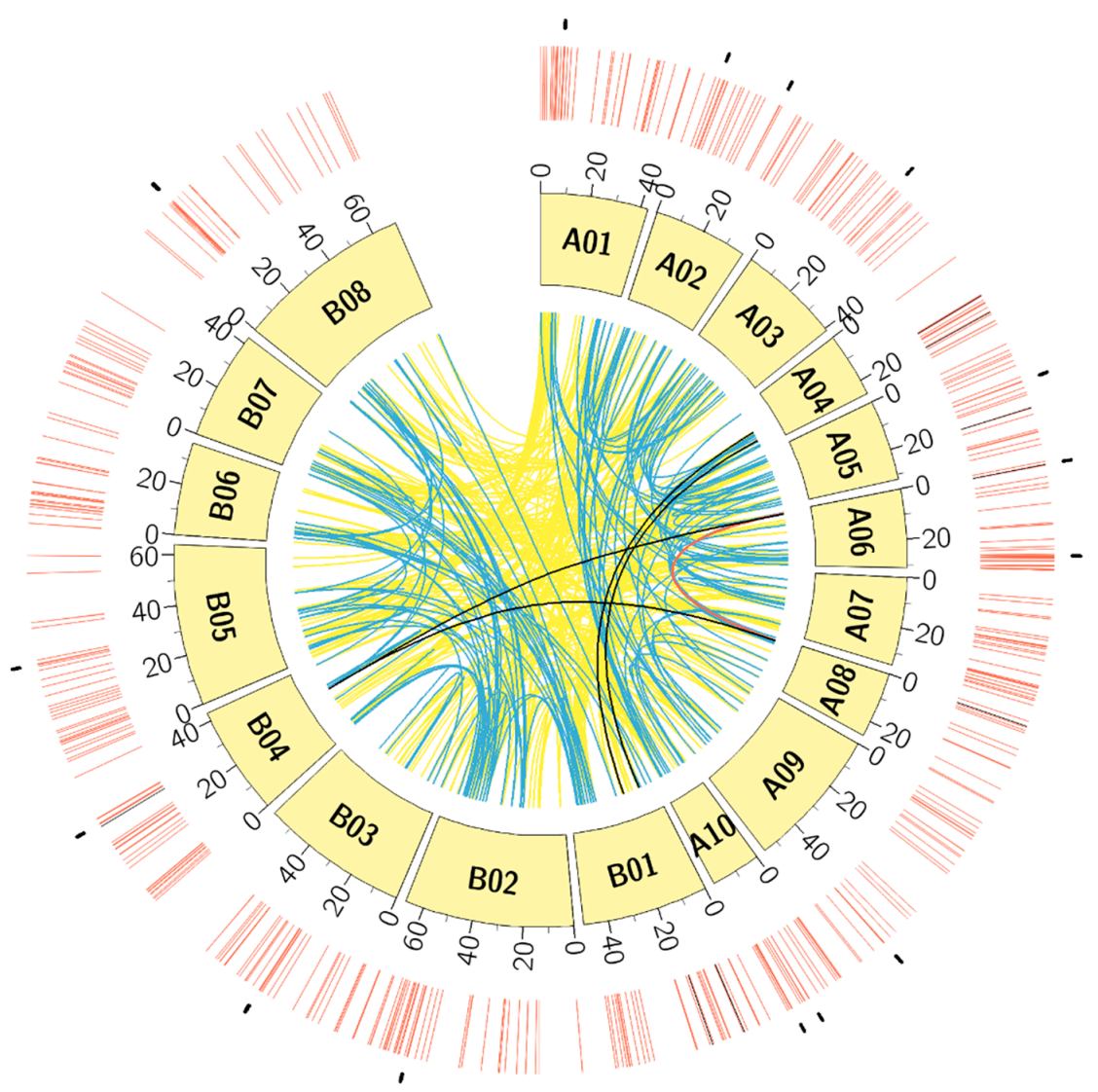

(B)

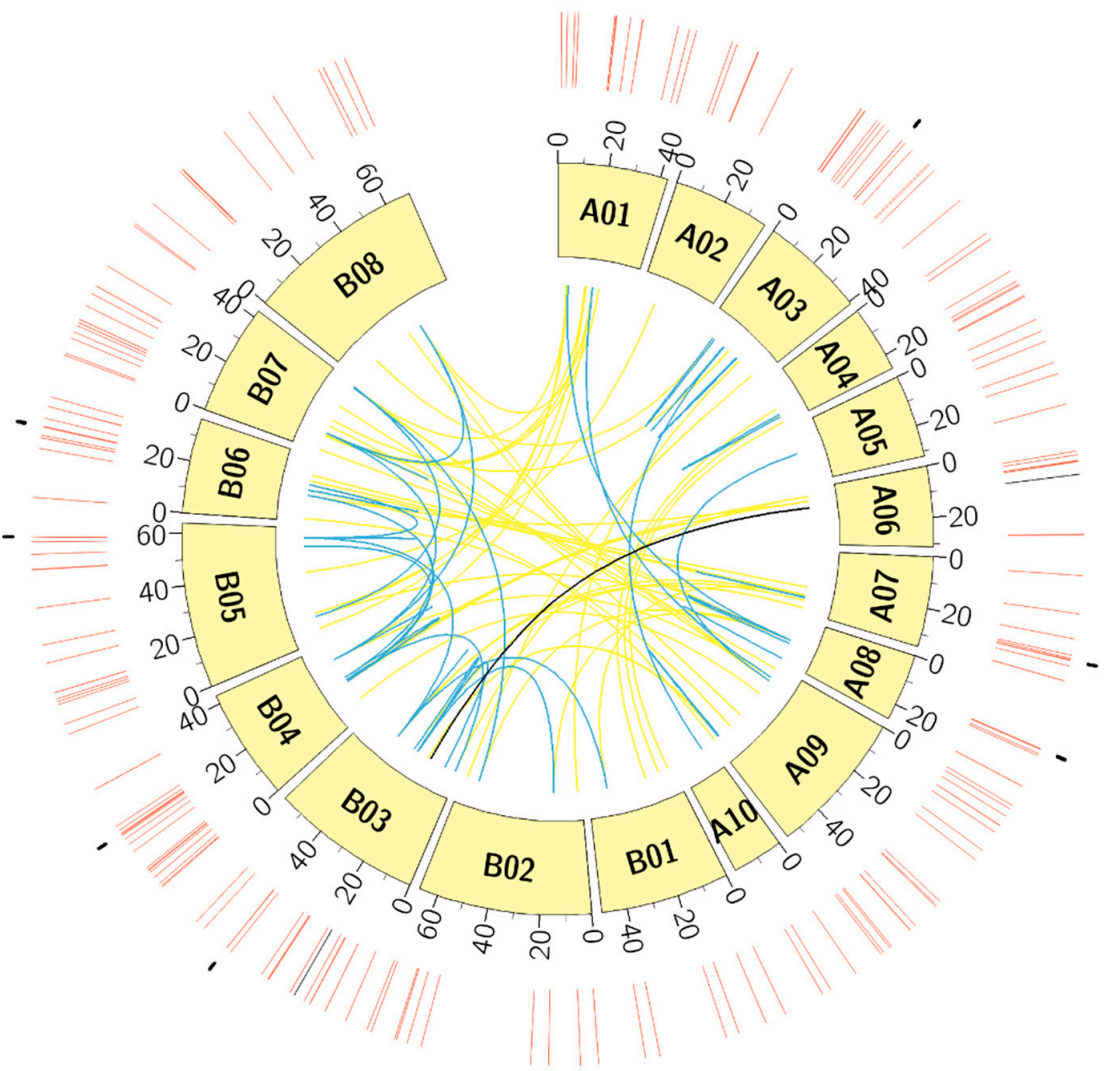

Figure 5. Chromosomal distribution, organisation and duplication of 458 candidate RLK genes (A) and 212 candidate RLP genes (B) in the B. juncea genome. 
The outer circle illustrates the position of RLK/RLP clusters. The LysM-RLK/RLP (black) and LRR-RLK/RLP (red) type genes were mapped on 18 chromosomes (A01-A10, B01-B08) in the inner circle. The coloured lines in the centre represent the duplication events between chromosomes: inter-genomic duplications of LRR-RLKs/RLPs (yellow) and LysM-RLKs/RLPs (black); intra-genomic duplication events of LRR-RLKs/RLPs (blue) and LysM-RLKs/RLPs (red).

Segmental duplications made minor contributions to RLK and RLP duplications. However, tandem duplications play a major role in RLP duplications compared to RLK duplications. In the duplicated RLK genes, 14.04\% (58 genes) were derived from tandem duplications, while only 3.87\% (16 genes) were from segmental duplications (Table S1). For the RLPs, $46.43 \%$ (52 genes) of the duplicated genes resulted from tandem duplication, while only $3.57 \%$ (4 genes) were from segmental duplications (Table S2).

The duplicated RLKs were mostly evenly distributed in the A and B sub-genomes in B. juncea, with 209 and 204 genes, respectively, consistent with the genomic distribution of duplicated RLPs, with 52 and 60 genes, respectively (Tables S1 and S2). However, these duplicated RLKs and RLPs were unevenly distributed over the 18 chromosomes of B. juncea (Figure 5; Tables S1 and S2). Additionally, the highest number of duplicated RLKs was found on chromosome B02, containing 34 LRR-RLKs, followed by B05 with 32 LRR-RLKs (Table S1). All of the LRR-RLKs residing on chromosomes A05 (21) and B07 (16) were involved in duplication events (Table S1). Chromosomes B03 and B04 had the highest number of duplicated RLPs, each containing 11 genes, while the least number (one) was found on chromosomes A02, A05 and A10 (Table S2).

In total, $82 \%$ (51 genes) of the clustered RLKs were found to be duplicated, as well as $88 \%$ (22 out of 25 genes) of clustered RLPs (Tables S1 and S2). Six out of 16 RLK clusters were formed by tandem duplication, while almost all of the RLP clusters (six out of seven) were defined as tandem clusters (Figures 1-3; Tables S1 and S2). For instance, the gene cluster on chromosome A02 contained three LRR-RLK genes, of which two were duplicates. Another example was the cluster on chromosome B08, constructed with three tandem duplicates.

A total of 471 and 110 duplication events were detected in the RLK and RLP families, respectively (Table 2). For both the RLK and RLP families, almost all of the duplication events occurred in the LRR sub-family, with 466 in LRR-RLKs and 109 in LRR-RLPs, in sharp contrast with five in LysM-RLKs and one in LysM-RLPs (Table 2).

Two types of duplication events, inter and intra duplications, were observed in both B. juncea RLK and RLP families (Table 2). For B. juncea RLKs, the number of inter-genomic duplications was much higher than intra-genomic, with 308 and 163, respectively. For the RLP family, the number of these two types of duplications was smaller, with 52 intragenomic duplications and 58 inter-genomic duplications (Table 2). Furthermore, the intragenomic duplications of RLKs were evenly distributed in B. juncea A and B genomes, with 83 and 80, respectively, while the RLP duplication events in the A genome (20) were less than in the B genome of 32 (Table 2). Almost all of the LysM-RLK duplications (four out of five) were defined as inter-genomic duplications, and in LysM-RLP, there was only one duplication event found between the A and B sub-genomes (Table 2). These two kinds of duplications for RLKs could be observed in all 18 chromosomes of B. juncea (Figure 5; Table S1). For RLPs, the B sub-genome contained both inter- and intra- genomic duplication events, while in the A sub-genome, the chromosomes A02 and A06 did not have intragenomic duplication and A05 and A10 did not have the inter-genomic type (Table S2). The duplicated events could be observed across the B. juncea genome (Figure 5).

\subsection{Phylogenetic Analysis of RLK and RLP Genes in B. juncea}

The evolutionary relationship between predicted proteins was studied by the construction of phylogenetic trees, using the neighbour-joining (NJ) method with 1000 bootstrap replicates (Figures S1 and S2). Here, the RLKs and RLPs were analysed separately. 
A total of 493 RLKs were divided into seven major groups, which were further classified into subgroups and clades (Figure S1). However, the size of the groups significantly varied, ranging from four in Group VI to 145 in Group I, with an average of 70 genes in each group. Additionally, all of the LysM-RLKs displayed a close relationship with some LRR-RLKs in Group I. In the phylogenetic tree, the predicted paralogous RLKs were grouped together with high bootstrap value. The majority of subgroups or clades consisted of paralogous genes located on the same chromosome or homeologous chromosomes, which were derived from duplications events. For example, LysM-RLK genes (BjuA002911 on chromosome A08, BjuA021332 on A06, and BjuB004835 on B04), defined as paralogous genes, were grouped together in Group I.

In total, 228 RLPs were classified into three primary groups through phylogenetic analysis (Figure S2). Similar to LysM-RLKs, LysM-RLPs were also closely related to some LRR-RLPs in Group III (Figure S2). Differently from RLKs, many branches were formed with a single RLP gene, suggesting the distant evolutionary relationship and the functional diversity among RLP genes (Figure S2).

3.6. Comparison and Conservation Analysis of RLK and RLP Genes between B. juncea and Its Diploid Progenitor Species B. rapa and B. nigra

B. juncea, an allotetraploid species (AABB), was generated through interspecific hybridisation between two ancestral diploid genomes of B. rapa (AA) and B. nigra (BB) $[32,33]$. Genomic comparison of RLKs and RLPs is important to understand the genetic diversity and evolution between these Brassica species.

In total, 493 RLKs and 228 RLPs were identified in B. juncea, of which 236 RLKs and 95 RLPs were located in the A genome, and the remaining genes resided in the B genome (Tables S1 and S2). In B. rapa, genome-wide identification indicated that $0.651 \%$ (300 genes) of the total predicted genes were detected as RLK genes, consisting of three LysM-RLKs and 297 LRR-RLKs, which is higher than in the B. juncea A genome (Tables 1 and 3). Conversely, 65 RLPs $(0.141 \%)$ in B. rapa, which included two LysM-RLPs and 63 LRR-RLPs, were less than those found in the B. juncea A genome with 95 genes (Tables 1 and 3). A total of 317 RLK genes $(0.636 \%$ of the total predicted genes) were identified from the B. nigra scaffold sequence, with five LysM-RLKs and 312 LRR-RLKs more than in the B genome of $B$. juncea. Similarly, the number of RLPs $(0.353 \%)$ in B. nigra was also higher than in B. juncea, with 176 and 117 genes, respectively (Tables 1, 4 and 5).

In these three Brassica species, the proportions of RLK genes were similar (around $0.613 \%$ to $0.651 \%$ ), while those of RLPs varied from $0.141 \%$ to $0.353 \%$ (Table 2). Additionally, LysM and LRR subgroups could be observed in each RLK and RLP family, while the percentage of the LysM subfamily was found to be extremely low, below $4 \%$, in both RLK and RLP families (Tables 3-5).

The chromosomal distribution and clustering of RLK and RLP genes were not analysed in B. nigra, as a good quality assembled genome was not available. Genes of the RLK family in the A genome of B. juncea shared a similar distribution pattern with B. rapa in gene number and distribution (Figure 6; Tables 3 and 4). For instance, chromosome A06 in B. juncea and B. rapa contained the highest number of RLKs, and the least number was observed in A04 and A08. Additionally, the chromosomal distribution pattern of the LRR-RLK subfamily was consistent with the RLK family in the A genomes of $B$. juncea and B. rapa (Figure 6; Tables 3 and 4). However, the distribution of LysM-RLK genes was slightly different between these two Brassica species, as the presence of LysM-RLK on chromosome A05 of B. juncea was not observed in B. rapa (Figure 6; Tables 3 and 4). 


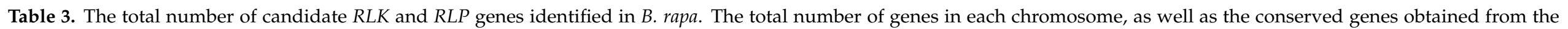
comparison with B. juncea.

\begin{tabular}{|c|c|c|c|c|c|c|c|c|c|c|c|c|c|c|c|c|c|}
\hline \multirow{3}{*}{ Chromosome } & & \multicolumn{8}{|c|}{ RLK } & \multicolumn{8}{|c|}{ RLP } \\
\hline & & \multirow[b]{2}{*}{ Total } & \multirow[b]{2}{*}{$\begin{array}{l}\text { LysM- } \\
\text { RLK }\end{array}$} & \multirow[b]{2}{*}{$\begin{array}{l}\text { LRR- } \\
\text { RLK }\end{array}$} & \multicolumn{2}{|c|}{ Gene Cluster } & \multicolumn{3}{|c|}{ Conserved } & \multirow[b]{2}{*}{ Total } & \multirow[b]{2}{*}{$\begin{array}{l}\text { LysM- } \\
\text { RLP }\end{array}$} & \multirow[b]{2}{*}{$\begin{array}{l}\text { LRR- } \\
\text { RLP }\end{array}$} & \multicolumn{2}{|c|}{ Gene Cluster } & \multicolumn{3}{|c|}{ Conserved } \\
\hline & & & & & $\begin{array}{l}\text { No. of } \\
\text { Cluster }\end{array}$ & $\begin{array}{c}\text { No. of } \\
\text { Gene in } \\
\text { Cluster }\end{array}$ & Total & $\begin{array}{l}\text { LysM- } \\
\text { RLK }\end{array}$ & $\begin{array}{l}\text { LRR- } \\
\text { RLK }\end{array}$ & & & & $\begin{array}{l}\text { No. of } \\
\text { Cluster }\end{array}$ & $\begin{array}{c}\text { No. of } \\
\text { Gene in } \\
\text { Cluster }\end{array}$ & Total & $\begin{array}{l}\text { LysM- } \\
\text { RLP }\end{array}$ & $\begin{array}{l}\text { LRR- } \\
\text { RLP }\end{array}$ \\
\hline A genome B. rapa & $\begin{array}{l}\text { A01 } \\
\text { A02 } \\
\text { A03 } \\
\text { A04 } \\
\text { A05 } \\
\text { A06 } \\
\text { A07 } \\
\text { A08 } \\
\text { A09 } \\
\text { A10 }\end{array}$ & $\begin{array}{l}36 \\
28 \\
38 \\
16 \\
25 \\
49 \\
37 \\
19 \\
26 \\
21\end{array}$ & $\begin{array}{l}0 \\
0 \\
0 \\
1 \\
0 \\
1 \\
0 \\
1 \\
0 \\
0\end{array}$ & $\begin{array}{l}36 \\
28 \\
38 \\
15 \\
25 \\
48 \\
37 \\
18 \\
26 \\
21\end{array}$ & $\begin{array}{l}1 \\
2 \\
0 \\
1 \\
1 \\
3 \\
3 \\
0 \\
0 \\
2\end{array}$ & $\begin{array}{c}5 \\
9 \\
0 \\
5 \\
7 \\
15 \\
12 \\
0 \\
0 \\
7\end{array}$ & $\begin{array}{l}29 \\
17 \\
30 \\
14 \\
19 \\
36 \\
21 \\
15 \\
16 \\
17\end{array}$ & $\begin{array}{l}0 \\
0 \\
0 \\
1 \\
0 \\
1 \\
0 \\
1 \\
0 \\
0\end{array}$ & $\begin{array}{l}29 \\
17 \\
30 \\
13 \\
19 \\
35 \\
21 \\
14 \\
16 \\
17\end{array}$ & $\begin{array}{l}10 \\
7 \\
9 \\
1 \\
6 \\
10 \\
4 \\
7 \\
9 \\
2\end{array}$ & $\begin{array}{l}0 \\
0 \\
0 \\
0 \\
0 \\
1 \\
0 \\
1 \\
0 \\
0\end{array}$ & $\begin{array}{l}10 \\
7 \\
9 \\
1 \\
6 \\
9 \\
4 \\
6 \\
9 \\
2\end{array}$ & $\begin{array}{l}0 \\
0 \\
0 \\
0 \\
1 \\
1 \\
0 \\
0 \\
0 \\
0\end{array}$ & $\begin{array}{l}0 \\
0 \\
0 \\
0 \\
3 \\
3 \\
0 \\
0 \\
0 \\
0\end{array}$ & $\begin{array}{l}5 \\
2 \\
2 \\
1 \\
4 \\
2 \\
2 \\
4 \\
4 \\
1\end{array}$ & $\begin{array}{l}0 \\
0 \\
0 \\
0 \\
0 \\
1 \\
0 \\
1 \\
0 \\
0\end{array}$ & $\begin{array}{l}5 \\
2 \\
2 \\
1 \\
4 \\
1 \\
2 \\
3 \\
4 \\
1\end{array}$ \\
\hline \multicolumn{2}{|c|}{ Total mapped genes } & 295 & $\begin{array}{c}3 \\
1.02 \%{ }^{1}\end{array}$ & $\begin{array}{c}292 \\
98.98 \%{ }^{1}\end{array}$ & 13 & $\begin{array}{c}60 \\
20.34 \%{ }^{1}\end{array}$ & $\begin{array}{c}214 \\
72.54 \%{ }^{1}\end{array}$ & $\begin{array}{c}3, \\
100.00 \%{ }^{2}\end{array}$ & $\begin{array}{c}211, \\
72.26 \%{ }^{3}\end{array}$ & 65 & $\begin{array}{c}2, \\
3.08 \% 1\end{array}$ & $\begin{array}{c}63 \\
96.92 \%{ }^{1}\end{array}$ & 2 & $\begin{array}{c}6, \\
9.23 \%{ }^{1}\end{array}$ & $\begin{array}{c}27 \\
41.54 \%{ }^{1}\end{array}$ & $\begin{array}{c}2, \\
100.00 \%{ }^{2}\end{array}$ & $\begin{array}{c}25, \\
39.68 \%{ }^{3}\end{array}$ \\
\hline \multicolumn{2}{|l|}{ Unassigned } & 5 & 0 & 5 & - & - & - & - & - & 0 & 0 & 0 & - & - & - & - & - \\
\hline \multicolumn{2}{|l|}{ Total } & 300 & $\begin{array}{c}3, \\
1.00 \% 4\end{array}$ & $\begin{array}{c}297 \\
99.00 \% 4\end{array}$ & 13 & - & - & - & - & 65 & $\begin{array}{c}2, \\
3.08 \% 4\end{array}$ & $\begin{array}{c}63 \\
96.92 \% 4\end{array}$ & 2 & - & - & - & - \\
\hline
\end{tabular}

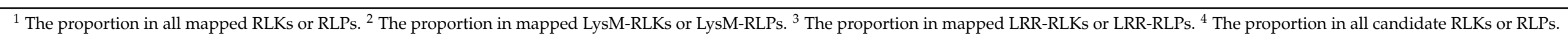




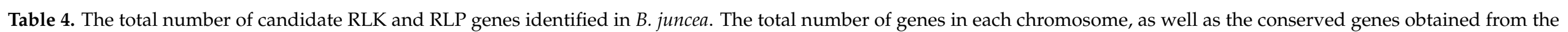
comparison with B. nigra and B. rapa. The total number of syntenic genes in each chromosome of B. juncea A genome, in contrast with B. rapa.

\begin{tabular}{|c|c|c|c|c|c|c|c|c|c|c|c|c|c|c|c|}
\hline \multirow{3}{*}{ Chromosome } & & \multicolumn{7}{|c|}{ RLK } & \multicolumn{7}{|c|}{ RLP } \\
\hline & & \multirow{2}{*}{ Total } & \multirow{2}{*}{ LysM- } & \multirow{2}{*}{ LRR- } & \multicolumn{3}{|c|}{ Conserved } & \multirow{2}{*}{$\begin{array}{l}\text { Syntenic } \\
\text { Genes }\end{array}$} & \multirow{2}{*}{ Total } & \multirow{2}{*}{ LysM } & \multirow{2}{*}{ LRR- } & \multicolumn{3}{|c|}{ Conserved } & \multirow{2}{*}{$\begin{array}{c}\text { Syntenic } \\
\text { Genes }\end{array}$} \\
\hline & & & & & Total & LysM- & LRR- & & & & & Total & LysM- & LRR- & \\
\hline A genome B. juncea & $\begin{array}{l}\text { A01 } \\
\text { A02 } \\
\text { A03 } \\
\text { A04 } \\
\text { A05 } \\
\text { A06 } \\
\text { A07 } \\
\text { A08 } \\
\text { A09 } \\
\text { A10 }\end{array}$ & $\begin{array}{l}30 \\
25 \\
29 \\
16 \\
22 \\
31 \\
26 \\
12 \\
23 \\
22\end{array}$ & $\begin{array}{l}0 \\
0 \\
0 \\
2 \\
1 \\
1 \\
0 \\
1 \\
0 \\
0\end{array}$ & $\begin{array}{l}30 \\
25 \\
29 \\
14 \\
21 \\
30 \\
26 \\
11 \\
23 \\
22\end{array}$ & $\begin{array}{l}24 \\
17 \\
26 \\
13 \\
18 \\
27 \\
22 \\
12 \\
17 \\
18\end{array}$ & $\begin{array}{l}0 \\
0 \\
0 \\
1 \\
0 \\
1 \\
0 \\
1 \\
0 \\
0\end{array}$ & $\begin{array}{l}24 \\
17 \\
26 \\
12 \\
18 \\
26 \\
22 \\
11 \\
17 \\
18\end{array}$ & $\begin{array}{l}22 \\
14 \\
28 \\
13 \\
19 \\
32 \\
21 \\
11 \\
15 \\
17\end{array}$ & $\begin{array}{c}12 \\
5 \\
17 \\
9 \\
6 \\
7 \\
11 \\
8 \\
17 \\
3\end{array}$ & $\begin{array}{l}0 \\
0 \\
0 \\
0 \\
0 \\
1 \\
0 \\
0 \\
0 \\
0\end{array}$ & $\begin{array}{c}12 \\
5 \\
17 \\
9 \\
6 \\
6 \\
11 \\
8 \\
17 \\
3\end{array}$ & $\begin{array}{l}6 \\
2 \\
1 \\
1 \\
1 \\
2 \\
2 \\
3 \\
5 \\
1\end{array}$ & $\begin{array}{l}0 \\
0 \\
0 \\
0 \\
0 \\
1 \\
0 \\
0 \\
0 \\
0\end{array}$ & $\begin{array}{l}6 \\
2 \\
1 \\
1 \\
1 \\
1 \\
2 \\
3 \\
5 \\
1\end{array}$ & $\begin{array}{l}5 \\
2 \\
1 \\
1 \\
3 \\
2 \\
2 \\
5 \\
5 \\
1\end{array}$ \\
\hline \multicolumn{2}{|c|}{ Total in A genome } & $\begin{array}{r}236, \\
51.53 \%{ }^{1} \\
\end{array}$ & $\begin{array}{c}5, \\
2.12 \%{ }^{2} \\
\end{array}$ & $\begin{array}{r}231 \\
97.88 \%{ }^{2} \\
\end{array}$ & $\begin{array}{c}194, \\
82.20 \%^{2} \\
\end{array}$ & $\begin{array}{c}3, \\
60.00 \%^{3} \\
\end{array}$ & $\begin{array}{c}191, \\
82.68 \%{ }^{4} \\
\end{array}$ & $\begin{array}{c}192, \\
81.36 \%^{2} \\
\end{array}$ & $\begin{array}{c}95 \\
44.81 \%^{1} \\
\end{array}$ & $\begin{array}{c}1, \\
1.05 \%{ }^{2} \\
\end{array}$ & $\begin{array}{c}94 \\
98.95 \%^{2} \\
\end{array}$ & $\begin{array}{c}24, \\
25.26 \%^{2} \\
\end{array}$ & $\begin{array}{c}1, \\
100.00 \%^{3} \\
\end{array}$ & $\begin{array}{c}23 \\
24.47 \%{ }^{4} \\
\end{array}$ & $\begin{array}{c}27 \\
28.42 \%^{2} \\
\end{array}$ \\
\hline B genome B. juncea & $\begin{array}{l}\text { B01 } \\
\text { B02 } \\
\text { B03 } \\
\text { B04 } \\
\text { B05 } \\
\text { B06 } \\
\text { B07 } \\
\text { B08 } \\
\end{array}$ & $\begin{array}{l}27 \\
36 \\
30 \\
30 \\
33 \\
20 \\
16 \\
30\end{array}$ & $\begin{array}{l}2 \\
0 \\
0 \\
1 \\
0 \\
0 \\
0 \\
0\end{array}$ & $\begin{array}{l}25 \\
36 \\
30 \\
29 \\
33 \\
20 \\
16 \\
30\end{array}$ & $\begin{array}{l}24 \\
30 \\
27 \\
23 \\
28 \\
17 \\
16 \\
24\end{array}$ & $\begin{array}{l}2 \\
0 \\
0 \\
1 \\
0 \\
0 \\
0 \\
0\end{array}$ & $\begin{array}{l}22 \\
30 \\
27 \\
22 \\
28 \\
17 \\
16 \\
24\end{array}$ & $\begin{array}{l}- \\
- \\
- \\
- \\
- \\
- \\
- \\
-\end{array}$ & $\begin{array}{c}6 \\
10 \\
19 \\
23 \\
18 \\
11 \\
16 \\
14\end{array}$ & $\begin{array}{l}0 \\
0 \\
1 \\
0 \\
0 \\
0 \\
0 \\
0\end{array}$ & $\begin{array}{c}6 \\
10 \\
18 \\
23 \\
18 \\
11 \\
16 \\
14\end{array}$ & $\begin{array}{c}6 \\
3 \\
13 \\
11 \\
11 \\
6 \\
9 \\
6\end{array}$ & $\begin{array}{l}0 \\
0 \\
1 \\
0 \\
0 \\
0 \\
0 \\
0\end{array}$ & $\begin{array}{c}6 \\
3 \\
12 \\
11 \\
11 \\
6 \\
9 \\
6\end{array}$ & $\begin{array}{l}- \\
- \\
- \\
- \\
- \\
- \\
- \\
-\end{array}$ \\
\hline \multicolumn{2}{|c|}{ Total mapped genes } & 458 & $\begin{array}{c}8, \\
1.75 \%{ }^{1}\end{array}$ & $\begin{array}{c}450, \\
98.25 \%{ }^{1}\end{array}$ & $\begin{array}{c}383 \\
83.62 \%{ }^{1}\end{array}$ & $\begin{array}{c}6 \\
75.00 \%^{3}\end{array}$ & $\begin{array}{c}377 \\
83.78 \%{ }^{4}\end{array}$ & - & 212 & $\begin{array}{c}2, \\
0.94 \%{ }^{1}\end{array}$ & $\begin{array}{c}210, \\
99.06 \%{ }^{1}\end{array}$ & $\begin{array}{c}89 \\
41.98 \%{ }^{1}\end{array}$ & $\begin{array}{c}2, \\
100.00 \%^{3}\end{array}$ & $\begin{array}{c}87 \\
41.43 \% \\
4\end{array}$ & - \\
\hline
\end{tabular}

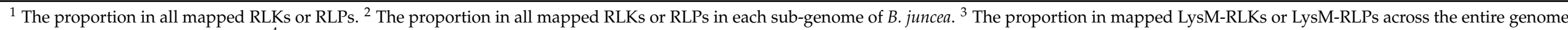
and each sub-genome of $B$. juncea. ${ }^{4}$ The proportion in mapped LRR-RLKs or LRR-RLPs across the entire genome and each sub-genome of $B . j u n c e a$. 
Table 5. The total number of candidate RLK and RLP genes identified in B. nigra scaffolds. The conserved genes obtained from the comparison with B. juncea and B. nigra.

\begin{tabular}{|c|c|c|c|}
\hline \multirow{2}{*}{ RLK } & \multicolumn{2}{|c|}{$\begin{array}{c}\text { Total } \\
\text { LysM-RLK } \\
\text { LRR-RLK }\end{array}$} & $\begin{array}{c}317 \\
5\left(1.58 \%{ }^{1}\right) \\
312\left(98.42 \%^{1}\right)\end{array}$ \\
\hline & Conserved & $\begin{array}{c}\text { Total } \\
\text { LysM-RLK } \\
\text { LRR-RLK }\end{array}$ & $\begin{array}{c}227\left(71.61 \%{ }^{1}\right) \\
4 \\
223\end{array}$ \\
\hline \multirow{2}{*}{ RLP } & \multicolumn{2}{|c|}{$\begin{array}{c}\text { Total } \\
\text { LysM-RLP } \\
\text { LRR-RLP }\end{array}$} & $\begin{array}{c}176 \\
1\left(0.57 \%^{2}\right) \\
175\left(99.43 \%^{2}\right)\end{array}$ \\
\hline & Conserved & $\begin{array}{c}\text { Total } \\
\text { LysM-RLP } \\
\text { LRR-RLP }\end{array}$ & $\begin{array}{c}72\left(40.91 \%{ }^{2}\right) \\
1 \\
71\end{array}$ \\
\hline
\end{tabular}

${ }^{1}$ The proportion in all RLKs. ${ }^{2}$ The proportion in all RLPs.

(A)
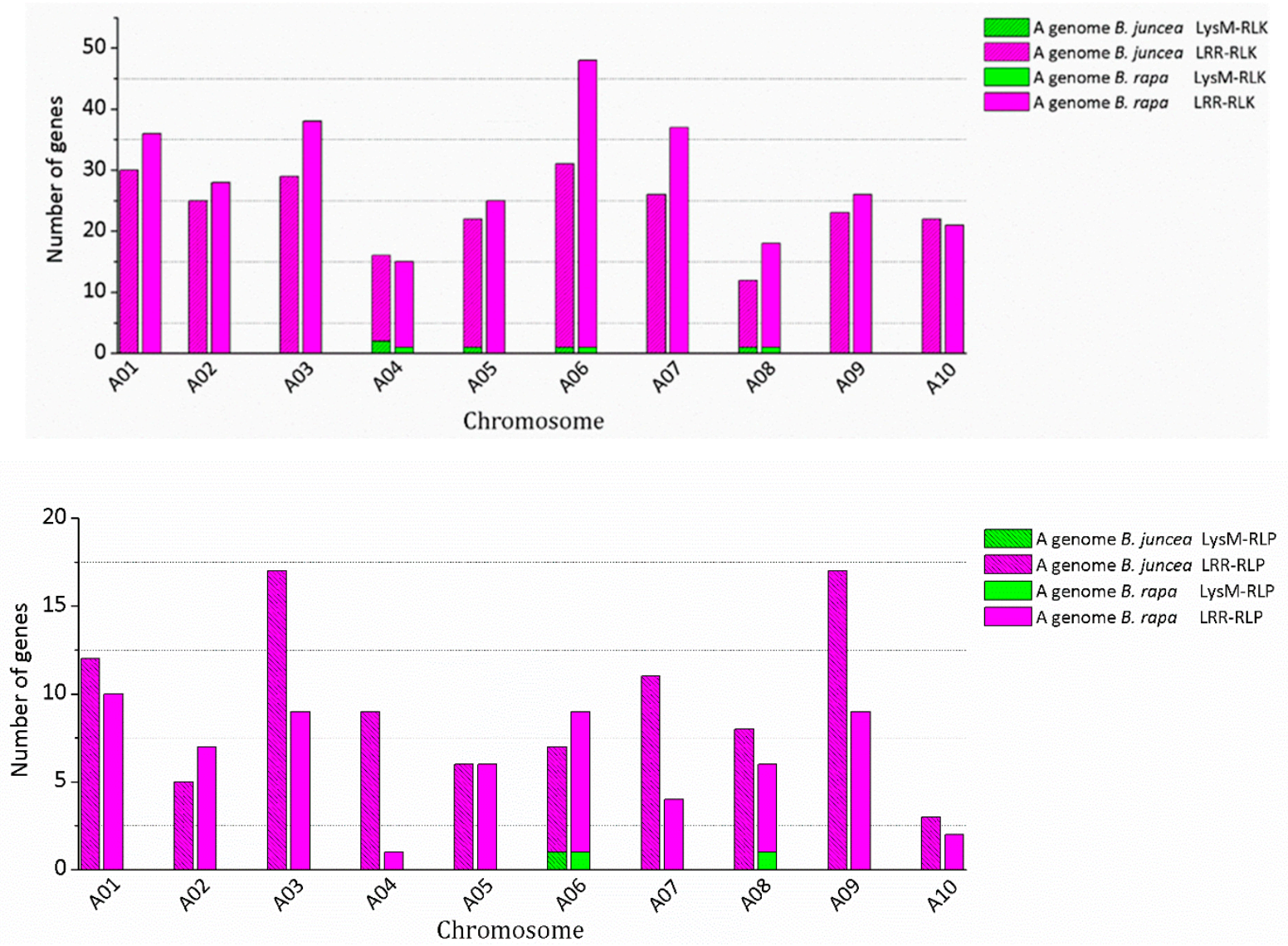

Figure 6. Distribution of candidate RLK (A) and RLP (B) genes in the A genome of B. juncea and B. rapa.

The chromosomal distribution of RLPs differed between the A genome of $B$. juncea and $B$. rapa (Figure 6; Tables 3 and 4). For instance, the highest number (17 genes) of RLPs were found on chromosomes A03 and A09 in the A genome of B. juncea, while it was observed on A01 and A06 of B. rapa, with 10 genes. Furthermore, a different distribution pattern could be observed in both the LRR-RLP or LysM-RLP subfamilies between the A genome of these two Brassica species (Figure 6; Tables 3 and 4). For example, the LysM-RLP gene, lost in B. juncea A08 was present in B. rapa. 
In B. rapa, 20.34\% (60 genes) of the mapped RLKs were found to be organised in 13 gene clusters, which was higher than 10 clusters grouped by 33 genes $(13.98 \%)$ in the $B$. juncea A genome (Table 3 and Table S1). Furthermore, the cluster distribution of RLKs and RLPs differed between B. juncea and B. rapa (Figures 7 and 8; Table 3, Tables S1 and S2). For instance, the RLP clusters in the B. juncea A genome were evenly located on chromosomes A03, A07 and A08, while they were equally distributed on A05 and A06 of B. rapa.

The identification of orthologous genes was performed between $B$. juncea and its diploid progenitors by comparing the protein sequences in each RLK and RLP family, respectively. In B. juncea, a total of 383 RLKs $(83.62 \%)$ and 89 RLPs $(41.98 \%)$ were considered as orthologous genes, of which 194 RLKs and 24 RLPs were mapped in the A genome, and the remaining genes were distributed in the B genome (Tables 4 and 6 ). The orthology analysis also indicated that there were 214 RLKs $(72.54 \%)$ and 27 RLPs $(41.54 \%)$ conserved in B. rapa and 227 RLKs and 72 RLPs maintained in B. nigra, with $71.61 \%$ and $40.91 \%$, respectively (Tables 3-6). In these Brassica species, the proportion of conserved RLK genes was higher than RLP genes.

Table 6. Comparative analysis of the number of RLK and RLP genes in B. juncea, B. nigra and B. rapa.

\begin{tabular}{|c|c|c|c|c|c|}
\hline Gene Family & Genome & $\begin{array}{c}\text { B. juncea } \\
\text { A Genome }\end{array}$ & $\begin{array}{c}\text { B. rapa } \\
\text { A Genome }\end{array}$ & $\begin{array}{l}\text { B. juncea } \\
\text { B Genome }\end{array}$ & $\begin{array}{l}\text { B. nigra } \\
\text { B Genome }\end{array}$ \\
\hline \multirow{7}{*}{ RLK family } & Total (LysM, LRR) & $236(5,231)$ & $300(3,297)$ & $222(3,219)$ & $317(5,315)$ \\
\hline & Total conserved & $194(82.20 \%)$ & $214(71.33 \%)$ & $189(85.14 \%)$ & $227(71.61 \%)$ \\
\hline & Conserved LysM-RLK & $3(60.00 \%)$ & $3(100.00 \%)$ & $3(100.00 \%)$ & $4(80.00 \%)$ \\
\hline & Conserved LRR-RLK & $191(82.68 \%)$ & $211(71.04 \%)$ & $186(84.93 \%)$ & $223(70.79 \%)$ \\
\hline & Not conserved & $42(17.80 \%)$ & $86(28.67 \%)$ & $33(14.86 \%)$ & $90(28.39 \%)$ \\
\hline & Lost & 0 & 86 & 0 & 90 \\
\hline & Gained & 42 & 0 & 33 & 0 \\
\hline \multirow{7}{*}{ RLP family } & Total (LysM, LRR) & $95(1,94)$ & $65(2,63)$ & $117(1,116)$ & $176(1,175)$ \\
\hline & Total conserved & $24(25.26 \%)$ & $27(41.54 \%)$ & $65(55.56 \%)$ & $72(40.91 \%)$ \\
\hline & Conserved LysM-RLP & $1(100.00 \%)$ & $2(100.00 \%)$ & $1(100.00 \%)$ & $1(100.00 \%)$ \\
\hline & Conserved LRR-RLP & $23(24.47 \%)$ & $25(39.68 \%)$ & $64(55.17 \%)$ & $71(40.57 \%)$ \\
\hline & Not conserved & $71(74.74 \%)$ & $38(58.46 \%)$ & $52(44.44 \%)$ & $104(59.09 \%)$ \\
\hline & Lost & 0 & 38 & 0 & 104 \\
\hline & Gained & 71 & 0 & 52 & 0 \\
\hline
\end{tabular}

Genomic distribution of orthologous genes indicated that the proportion of conserved RLKs in each sub-genome of B. juncea $(82.20 \%$ and $85.14 \%)$ was higher than B. rapa $(72.54 \%)$ and B. nigra $(71.61 \%)$, respectively (Tables $3-6)$. Similarly, the percentage of conserved RLPs was also higher in the B genome of B. juncea (55.56\%) than its progenitor B. nigra $(40.91 \%)$, while obviously lower in the A genome of B. juncea than B. rapa, with $25.26 \%$ and $41.54 \%$, respectively (Tables 3-6).

In B. juncea, 86 RLKs and 38 RLPs were found to be lost in the A genome, and 90 RLKs and 104 RLPs were absent in the B genome, compared to its diploid progenitors (Table 6). Additionally, some RLKs and RLPs were only observed in B. juncea, including 42 RLKs and 71 RLPs in the A genome and 33 RLKs and 52 RLPs in the B genome (Table 6). 


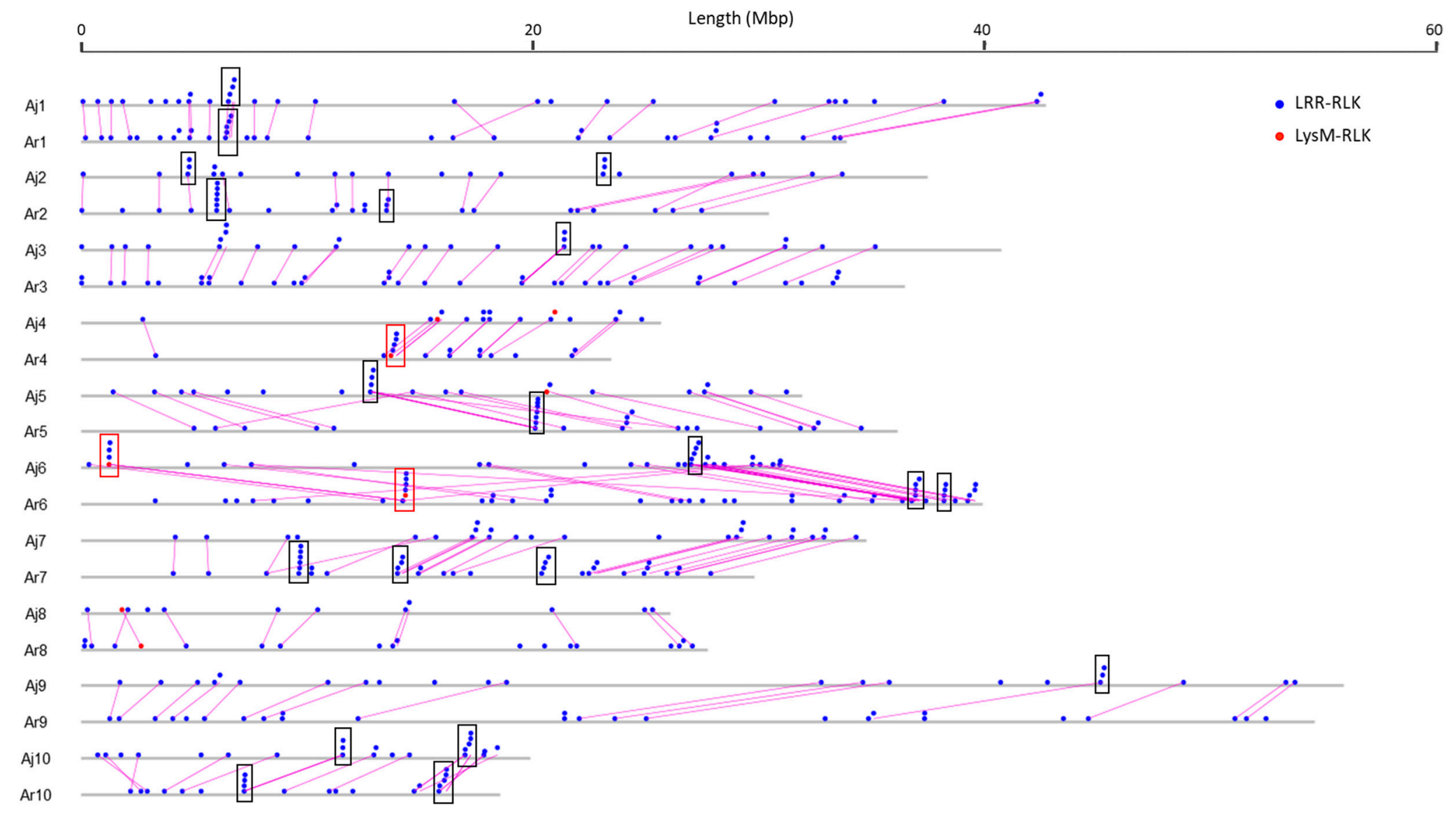

Figure 7. Comparative organisation of RLK genes between Aj genome of B. juncea and Ar genome of B. rapa (chromosomes A01 to A10). Solid circles above the chromosome (grey bars) represented RLK genes: LysM-RLK (red) and LRR-RLK (blue). Rectangles represented gene clusters: homogeneous cluster (black) and heterogeneous cluster (red). Pink straight lines between genes displayed the genes with syntenic relationship between B. juncea and B. rapa. Chromosome lengths were displayed in Mbp (megabase pairs) on the scale at top. 


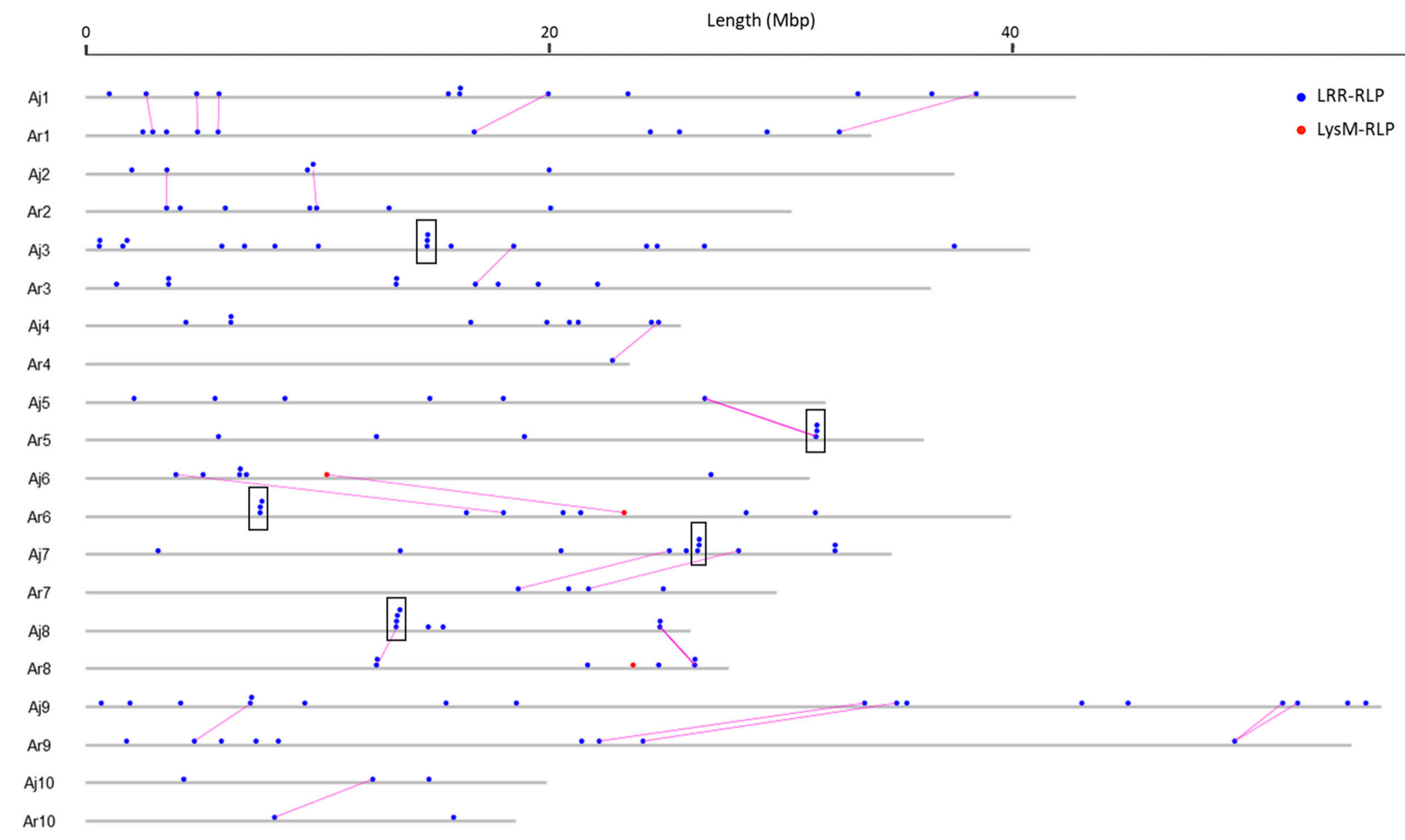

Figure 8. Comparative organisation of RLP genes between Aj genome of B. juncea and Ar genome of B. rapa (chromosomes A01 to A10). Solid circles above the chromosome (grey bars) represented RLK genes: LysM-RLP (red) and LRR-RLP (blue). Black rectangles represented homogeneous cluster. Pink straight lines between genes displayed the genes with syntenic relationship between B. juncea and B. rapa. Chromosome lengths were displayed in Mbp (megabase pairs) on the scale at top. 
The synteny relationship of RLK and RLP genes in the A genome was assessed between $B$. juncea and its diploid progenitor $B$. rapa on the basis of an orthologous analysis and their physical positions. This analysis, which was separately performed in the RLK and RLP families, indicated that the distribution of RLKs and RLPs displayed obvious synteny and a collinear relationship between the A genomes of $B$. juncea and $B$. rapa (Figures 7 and 8). In the B. juncea A genome, a total of 192 RLKs (81.36\%) were found to be in synteny and collinear with B. rapa (Table 4). However, only $28.42 \%$ (27 genes) of the total RLP genes in the $B$. juncea A genome were observed to be in synteny and collinear with B. rapa (Table 4 ).

\section{Discussion}

\subsection{Genome Wide Identification of RLK and RLP Genes in B. juncea}

The number of LRR-RLKs in $B$. juncea is notably higher than the number in $B$. rapa with 303 genes [52], A. thaliana containing 213 genes [54], O. sativa having 309 [55] and P. trichocarpa having 379 [56]. This is probably due to the large allotetraploid genome of B. juncea (AABB) [33]. Similarly, a higher number of LRR-RLKs has also been identified in polyploid T. aestivum and G. max, with 531 and 467 genes, respectively [48,57-59], and allotetraploid B. napus cv. Darmor V4 (596 genes) [60]. Accordingly, the LRR-RLP number in $B$. juncea is also higher than in the diploids B. rapa and B. nigra analysed in this study and the plants previously reported, including A. thaliana (57) [12], O. sativa (90) [21] and P. trichocarpa (82) [20].

Here, the content of LysM of RLKs and RLPs is extremely low in the studied species. Similarly, the number of LysM-RLKs and LysM-RLPs is also very low in previous reports across species from the Brassicaceae family [60]. To date, the highest number (17) of LysMRLKs have been separately observed in L. japonicas and M. truncatula [61,62], followed by G. max and P. trichocarpa with 12 and 11 genes, respectively [63], while less than 10 genes have been observed in $A$. thaliana (5 genes) and $O$. sativa (6 genes) [62,63]. For LysM-RLPs, there are three genes found in A. thaliana, [64,65], four in G. max, two in M. truncatula, seven in $P$. trichocarpa and six in O. sativa [65].

The distribution of RLKs and RLPs on the majority of chromosomes was uneven. The distribution pattern of LRR-RLK in B. rapa, detected in this study, is consistent with the previous report [52]. The uneven distribution of LRR-RLKs is not novel in plants' genomes [18], as has been demonstrated in other plant species recently, including S. lycopersicum [46], T. aestivum [48], two Glycine species (G. max and G. latifolia) $[57,66]$ and two Citrus species (C. clementina and C. sinensis) [67]. While the genome-wide study of LRR-RLPs is limited in several plant species, only O. sativa and Arabidopsis had their distribution analysed, where they exhibit a similar pattern [21] compared with our study. Additionally, the unequal distribution of genes across sub-genomes was also observed in other Brassica gene families, such as the NLR family in B. juncea [41], B. napus [45] and B. rapa [68] and the chitinase family in B. rapa [69]. Moreover, in this study, many RLKs and RLPs were grouped within the gene clusters. The formation of resistance-gene clusters is thought to facilitate the evolution of resistance genes through sequence exchanges via unequal crossing over, recombinatorial mispairing, or generating high haplotypic diversity [70,71].

\subsection{RLK and RLP Gene Duplication in B. juncea}

Gene duplication, as a result of whole-genome duplication, segmental duplication, tandem duplication and transposition events, is believed to contribute significantly to evolutionary innovation and gene family expansion, which allow the plants to be "buffered" against selective pressure in natural environments [72,73].

In this study, approximately $90 \%$ of the assigned RLKs have been found to be duplicated, suggesting that gene duplications contribute significantly to enlarge the RLK family in B. juncea. Although the duplicated proportion of RLPs is lower than RLKs, the 53\% duplication rate indicates that gene duplication also plays major roles in the expansion of $B$, juncea RLPs. Only around $4 \%$ of duplications in both the RLK and RLP families is 
considered as segmental duplications, suggesting that segmental duplications contribute minimally to the expansion of RLKs and RLPs. However, tandem duplications are likely to be mainly responsible for RLP duplications, due to around $50 \%$ duplications being defined as tandem duplications, yet they play minor roles in RLK duplications. Tandem duplication has been reported to be mainly responsible for the expansion of the LRR-RLK subfamily in O. sativa [55,74] and five Rosaceae species [75], as well as two additional $O$. sativa gene families, RLP and NLR [21,76]. However, this kind of duplication plays a minor role to enlarge the LRR-RLK sub-family in A. thaliana, G. max and S. lycopersicum, with around $15 \%, 20.3 \%$ and $12 \%$ of LRR-RLKs being tandemly duplicated, respectively $[46,57,74]$. In P. trichocarpa and G. max, the explosion of LRR-RLKs is significantly caused by segmental duplications, with approximately $82 \%$ and $73.3 \%$, respectively [56,57], compared with about $11 \%$ in $O$. sativa and around $26 \%$ in A. thaliana [74]. Additionally, these two major mechanisms proved to play primary roles in the expansion of LRR-RLK subfamily in B. rapa and RLK/Pelle family in A. thaliana [22,52].

In the Brassica species, all of the genomes have undergone a lineage-specific wholegenome triplication. The number of genes increased after many rounds of duplication [77-80]. Thus, we speculate that the expansion of RLK and RLP genes is probably mainly caused by whole-genome duplication. After speciation, B. juncea underwent substantial genome reshuffling and chromosomal rearrangements [33,81-83], which probably resulted in the random distribution of duplicated RLKs and RLPs across the $B$. juncea genome.

Here, $37.50 \%$ RLK clusters and $85.71 \%$ RLP clusters in $B$. juncea were generated by tandemly duplicated genes, indicating that tandem duplication events should be responsible for the origin of the genes in each cluster, which also have been proved in some species, including monocots A. trichopoda and $O$. sativa $[55,84]$, eudicots $P$. trichocarpa and G. $\max [56,57]$. Some inter-genomic duplications are likely to be from homoeologous regions and the duplication is due to polyploidization.

\subsection{Phylogenetic Analysis}

In this study, the phylogenetic trees were generated using full-length protein sequences of RLKs and RLPs. Full protein sequences of LRR-RLKs, which can provide excellent evolutionary inference, have been used for phylogenetic analysis with the neighbourjoining (NJ) method in many plants [48,52]. In both the RLK and RLP families, the predicted paralogous sequences, which are derived by gene duplications, are closely grouped together on the same or a close clade. Similarly, this has been observed in A. thaliana, B. rapa, O. sativa, $P$. trichocarpa and T. aestivum, due to paralogous sequences generated by duplication events and having similar domain architecture $[21,48,52]$. This number of paralogous sequences indicates that gene duplication plays an important role in the expansion of this family. The divergence of the sequences may be consistent with divergence in function of the genes in these families, as they are known to play roles in a large number of processes and not just disease resistance. Linking the genes involved in disease to specific clades may aid in the identification of candidate genes.

In phylogenetic analysis, protein sequences of the RLP family have formed many distinct clades constructed by branches with a single gene, compared to RLKs. This indicates that RLPs have undergone faster evolution and maintained relatively more diversity in sequence than RLKs, due to greater selective pressure on the RLPs. This phenomenon is also shown in the NLR family, of which the CNL family is more highly diverged than the TNL family in the Cucurbitaceae, Fabaceae, Brassicaceae, Poaceae and Solanaceae species $[45,76,85,86]$.

\subsection{Comparative Analysis of RLK and RLP Genes in B. juncea to Its Related Diploid Progenitor Species B. rapa and B. nigra}

The comparison between B. juncea and its progenitors (B. rapa and B. nigra) reveals RLKs and RLPs are reduced in $B$. juncea, probably due to gene loss during the polyploidization events. This was also observed in the B. juncea NLR family [41]. The gene reduction of NLR family has also been reported in B. napus, compared with its progenitors B. rapa 
and B. oleracea [45]. Additionally, LRR-RLK gene reduction has been observed in other species. For example, Triticum aestivum (wheat), an allohexaploid species with AABBDD genome, was found to contain 531 LRR-RLKs, distributed in the A, B and D sub-genomes, with 166, 195 and 170 genes, respectively, while the gene number of A and D sub-genomes is lower than its progenitors Triticum urartu (AA, 217 genes) and Aegilops tauschii (DD, 248 genes) [48,58,87-89].

The proportions of LRR-RLK genes in B. juncea, B. rapa and B. nigra are consistent with estimates of LRR-RLK for other angiosperm species, ranging from $0.67 \%$ to $1.39 \%$ [90]. Therefore, the gene number of LRR-RLKs seems not to be correlated with genome size, which can also be observed in LysM-RLKs and RLPs in this study. Similarly, the gene number of NLRs seems to be nonlinearly related with the total predicted gene number, and is unproportional to genome size in B. napus, B. rapa and B. oleracea $[45,91]$. It has been reported that a total of 303 LRR-RLK genes were identified in B. rapa [52], 10 genes more than that found in the present study. Thus, the difference of gene number is likely caused by using different detection criteria and different reference versions of $B$. rapa genome, here we used B. rapa v2.5 updated by Cai, Wang, Liu, Wu, Liang, Cui, Cheng and Wang [42].

The RLPs and RLKs in the A genome of $B$. juncea are consistent with B. rapa in their distribution and synteny. In particular, the gene families are highly conserved in size and orientation, similar to the $B$. napus NLR family [45]. The gene conservation and syntenic relationship has been found previously in many plants, such as G. max, A. thaliana and B. nigra, Solanaceae species, T. urartu and T. aestivum [92-97].

Furthermore, significant genomic co-linearity has been reported between B. napus and its diploid progenitors B. rapa and B. oleracea $[98,99]$. Therefore, we speculate that RLKs and RLPs in the $B$. juncea $B$ genome are also syntenic to $B$. nigra, although a high quality genome assembly of $B$. nigra is not yet available for comparison. However, the absence of synteny in some gene clusters and the presence of non-orthologous genes, which have been observed in the A genome of $B$. juncea in contrast with $B$. rapa, suggest occurrences of gene deletion, translocation and divergence in the $B$. juncea A genome after speciation. This was also reported in the NLR gene family between B. napus and its progenitors [45].

Orthology analysis indicates that over $82 \%$ RLKs are found to be conserved and maintained in B. juncea, compared to B. rapa and B. nigra. For RLP genes, the conserved proportion is consistent between the $B$ genome of $B$. juncea and B. nigra, whereas the RLP conserved proportion is much lower in the $B$. juncea A genome than its progenitor $B$. rapa. This indicates that RLPs in the A genome are more diverse than the in the $\mathrm{B}$ genome. The presence of orthologous genes suggests these genes have been retained after genome polyploidization. In plants, disease resistance genes, such as NLR, RLK and RLP families are highly duplicated and have undergone diversifying selection compared to other developmental genes $[21,100,101]$. Thus, these orthologous copies, which are found to be located in syntenic region between $B$. juncea and its progenitors, probably maintain their original function in the growth and development of $B$. juncea. Non-orthologous genes in $B$. juncea are likely to be specific or gained novel disease resistance.

The gene number of RLKs and RLPs varies within species due to gene losses and/or expansion through duplication and/or divergence $[48,67,75,84,90,101]$. Moreover, gene loss and gain was reported in B. juncea previously, compared to its related diploids [33]. In this study, the differences in gene number of conserved RLKs and RLPs between $B$. juncea and its diploid progenitors indicates the gene loss and gain in B. juncea. Reduction in RLKs and RLPs, which is primarily caused by gene loss during polyploidizations, was observed in B. juncea, compared to B. rapa and B. nigra. Simultaneously, gene duplication and recombination of RLKs and RLPs does not generate novel disease resistance genes specific to $B$. juncea.

In polyploids, the duplicated disease resistance genes were found to be preferentially lost after genome duplication, and most of the gene losses were probably driven by a deletion mechanism [102]. In B. juncea, the gene loss of RLKs and RLPs are likely caused by species-specific gene deletion after natural hybridisation of $B$. juncea from B. rapa and 
B. nigra. A similar kind of deletion was also reported in T. aestivum gene families: LRRRLK, lectin receptor kinases and Glyceraldehyde-3-phosphate dehydrogenase $[48,49,103]$, and the NLR family in B. napus [45].

In summary, a notable deletion of RLKs and RLPs was not observed in B. juncea, compared to its diploid progenitors, B. rapa and B. nigra. Evolutionary selection may play a minor role in maintaining the properties of $B$. juncea RLKs, compared with $B$. rapa and $B$. nigra, while being responsible for the diversity of $B$. juncea RLP genes.

\section{Conclusions}

In this study, the sub-families of B. juncea LRR-RLK and LRR-RLP are found to be larger than those in most reported plants. Furthermore, most of the RLK and RLP genes are not grouped within the clusters (singletons). Moreover, the occurrence of numerous paralogous genes of RLKs and RLPs indicates that gene duplications significantly contribute to the expansion of RLK and RLP families during the evolution process. Additionally, tandem duplications play major roles in RLP duplications, while segmental duplications make limited contributions to RLK and RLP duplications.

The comparative genome analysis indicates that gene loss and gain of RLKs and RLPs are observed in B. juncea, compared to its diploid progenitors, B. rapa and B. nigra. Furthermore, RLK and RLP genes show syntenic relationships with $B$. rapa in the A genome. The presence of orthologous genes suggests the remaining of conserved RLKs and RLPs after $B$. juncea speciation. However, RLPs are likely to have a faster evolution than RLKs.

The identification and characterisation of these genes will provide a useful resource for Brassica researchers undertaking the identification of resistance genes for Brassica crop improvement or for evolutionary studies.

Supplementary Materials: The following are available online at https:/ / www.mdpi.com/2079-773 7/10/1/17/s1, Figure S1: Phylogenetic analysis of RLK proteins of B. juncea, Figure S2: Phylogenetic analysis of RLP proteins of $B$. juncea, Table S1: The distribution and organisation of candidate RLK genes in B. juncea, Table S2: The distribution and organisation of candidate RLP genes in B. juncea.

Author Contributions: Conceptualization, H.Y., D.E. and J.B.; methodology, H.Y. and P.E.B.; validation, H.Y. formal analysis, H.Y., S.T. and P.EB.; investigation, H.Y. and P.E.B.; writing-original draft preparation, H.Y.; writing-review and editing, D.E., J.B. and S.T.; supervision, J.B. and D.E.; funding acquisition, J.B. and D.E. All authors have read and agreed to the published version of the manuscript.

Funding: This research was funded by ARC, grant number FT130100604, DP1601004497, LP140100537 and LP160100030.

Institutional Review Board Statement: Not applicable.

Informed Consent Statement: Not applicable.

Data Availability Statement: The data presented in this study are available in supplementary Table S1.

Conflicts of Interest: The authors declare no conflict of interest.

\section{References}

1. Monaghan, J.; Zipfel, C. Plant pattern recognition receptor complexes at the plasma membrane. Curr. Opin. Plant Biol. 2012, 15, 349-357. [CrossRef] [PubMed]

2. Wolf, S. Plant cell wall signalling and receptor-like kinases. Biochem. J. 2017, 474, 471-492. [CrossRef] [PubMed]

3. Wu, Y.; Zhou, J.M. Receptor-like kinases in plant innate immunity. J. Integr. Plant Biol. 2013, 55, 1271-1286. [CrossRef] [PubMed]

4. Zhang, Z.; Thomma, B.P.H.J. Structure-function aspects of extracellular leucine-rich repeat-containing cell surface receptors in plants. J. Integr. Plant Biol. 2013, 55, 1212-1223. [CrossRef]

5. Cai, W.; Zhang, D. The role of receptor-like kinases in regulating plant male reproduction. Plant Reprod. 2018, 31, 77-87. [CrossRef]

6. Ye, Y.; Ding, Y.; Jiang, Q.; Wang, F.; Sun, J.; Zhu, C. The role of receptor-like protein kinases (RLKs) in abiotic stress response in plants. Plant Cell Rep. 2017, 36, 235-242. [CrossRef]

7. Tang, D.; Wang, G.; Zhou, J.M. Receptor kinases in plant-pathogen interactions: More than pattern recognition. Plant Cell 2017, 29, 618-637. [CrossRef] 
8. Kruijt, M.; de Kock, M.J.; de Wit, P.J. Receptor-like proteins involved in plant disease resistance. Mol. Plant Pathol. 2005,6 , 85-97. [CrossRef]

9. Wang, G.; Fiers, M.; Ellendorff, U.; Wang, Z.; de Wit, P.J.; Angenent, G.C.; Thomma, B.P. The diverse roles of extracellular leucine-rich repeat-containing receptor-like proteins in plants. Crit. Rev. Plant Sci. 2010, 29, 285-299. [CrossRef]

10. Shiu, S.H.; Bleecker, A.B. Plant receptor-like kinase gene family: Diversity, function, and signaling. Sci. Stke 2001, $2001,22$. [CrossRef]

11. Shiu, S.H.; Karlowski, W.M.; Pan, R.; Tzeng, Y.H.; Mayer, K.F.; Li, W.H. Comparative analysis of the receptor-like kinase family in Arabidopsis and rice. Plant Cell 2004, 16, 1220-1234. [CrossRef] [PubMed]

12. Wang, G.; Ellendorff, U.; Kemp, B.; Mansfield, J.W.; Forsyth, A.; Mitchell, K.; Bastas, K.; Liu, C.M.; Woods-Tör, A.; Zipfel, C.; et al. A genome-wide functional investigation into the roles of receptor-like proteins in Arabidopsis. Plant Physiol. 2008, 147, 503. [CrossRef] [PubMed]

13. Liebrand, T.W.; van den Berg, G.C.; Zhang, Z.; Smit, P.; Cordewener, J.H.; America, A.H.; Sklenar, J.; Jones, A.M.; Tameling, W.I.; Robatzek, S. Receptor-like kinase SOBIR1/EVR interacts with receptor-like proteins in plant immunity against fungal infection. Proc. Natl. Acad. Sci. USA 2013, 110, 10010-10015. [CrossRef]

14. Liebrand, T.W.; van den Burg, H.A.; Joosten, M.H. Two for all: Receptor-associated kinases SOBIR1 and BAK1. Trends Plant Sci. 2014, 19, 123-132. [CrossRef] [PubMed]

15. Gust, A.A.; Felix, G. Receptor like proteins associate with SOBIR1-type of adaptors to form bimolecular receptor kinases. Curr. Opin. Plant Biol. 2014, 21, 104-111. [CrossRef] [PubMed]

16. Jones, D.A.; Thomas, C.M.; Hammond-Kosack, K.E.; Balint-Kurti, P.J.; Jones, J.D.G. Isolation of the tomato Cf-9 gene for resistance to Cladosporium fulvum by transposon tagging. Science 1994, 266, 789-793. [CrossRef] [PubMed]

17. Walker, J.C.; Zhang, R. Relationship of a putative receptor protein kinase from maize to the S-locus glycoproteins of Brassica. Nature 1990, 345, 743. [CrossRef]

18. Shiu, S.H.; Bleecker, A.B. Receptor-like kinases from Arabidopsis form a monophyletic gene family related to animal receptor kinases. Proc. Natl. Acad. Sci. USA 2001, 98, 10763-10768. [CrossRef]

19. Fischer, I.; Diévart, A.; Droc, G.; Dufayard, J.F.; Chantret, N. Evolutionary dynamics of the leucine-rich repeat receptor-like kinase (LRR-RLK) subfamily in Angiosperms. Plant Physiol. 2016, 170, 1595-1610. [CrossRef]

20. Petre, B.; Hacquard, S.; Duplessis, S.; Rouhier, N. Genome analysis of poplar LRR-RLP gene clusters reveals RISP, a defense-related gene coding a candidate endogenous peptide elicitor. Front. Plant Sci. 2014, 5, 111. [CrossRef]

21. Fritz-Laylin, L.K.; Krishnamurthy, N.; Tör, M.; Sjölander, K.V.; Jones, J.D.G. Phylogenomic analysis of the receptor-like proteins of rice and Arabidopsis. Plant Physiol. 2005, 138, 611-623. [CrossRef] [PubMed]

22. Shiu, S.H.; Bleecker, A.B. Expansion of the receptor-like kinase/pelle gene family and receptor-like proteins in Arabidopsis. Plant Physiol. 2003, 132, 530-543. [CrossRef] [PubMed]

23. Miya, A.; Albert, P.; Shinya, T.; Desaki, Y.; Ichimura, K.; Shirasu, K.; Narusaka, Y.; Kawakami, N.; Kaku, H.; Shibuya, N. CERK1, a LysM receptor kinase, is essential for chitin elicitor signaling in Arabidopsis. Proc. Natl. Acad. Sci. USA 2007, 104, 19613-19618. [CrossRef] [PubMed]

24. Erwig, J. Analysis of the Subcellular Behavior of Arabidopsis thaliana LysM-Proteins and Their Role in Plant Innate Immunity. Ph.D. Thesis, Georg-August-Universität Göttingen, Göttingen, Germany, April 2016.

25. Wan, J.; Zhang, X.C.; Neece, D.; Ramonell, K.M.; Clough, S.; Kim, S.Y.; Stacey, M.G.; Stacey, G. A LysM receptor-like kinase plays a critical role in chitin signaling and fungal resistance in Arabidopsis. Plant Cell 2008, 20, 471-481. [CrossRef]

26. Petutschnig, E.K.; Jones, A.M.; Serazetdinova, L.; Lipka, U.; Lipka, V. The lysin motif receptor-like kinase (LysM-RLK) CERK1 is a major chitin-binding protein in Arabidopsis thaliana and subject to chitin-induced phosphorylation. J. Biol. Chem. 2010, 285, 28902-28911. [CrossRef]

27. Kelly, S.; Radutoiu, S.; Stougaard, J. Legume LysM receptors mediate symbiotic and pathogenic signalling. Curr. Opin. Plant Biol. 2017, 39, 152-158. [CrossRef]

28. Gust, A.A.; Willmann, R.; Desaki, Y.; Grabherr, H.M.; Nürnberger, T. Plant LysM proteins: Modules mediating symbiosis and immunity. Trends Plant Sci. 2012, 17, 495-502. [CrossRef]

29. Limpens, E.; Franken, C.; Smit, P.; Willemse, J.; Bisseling, T.; Geurts, R. LysM domain receptor kinases regulating rhizobial nod factor-induced infection. Science 2003, 302, 630-633. [CrossRef]

30. Madsen, E.B.; Madsen, L.H.; Radutoiu, S.; Olbryt, M.; Rakwalska, M.; Szczyglowski, K.; Sato, S.; Kaneko, T.; Tabata, S.; Sandal, N A receptor kinase gene of the LysM type is involved in legume perception of rhizobial signals. Nature 2003, 425, 637. [CrossRef]

31. Radutoiu, S.; Madsen, L.H.; Madsen, E.B.; Felle, H.H.; Umehara, Y.; Grønlund, M.; Sato, S.; Nakamura, Y.; Tabata, S.; Sandal, N. Plant recognition of symbiotic bacteria requires two LysM receptor-like kinases. Nature 2003, 425, 585. [CrossRef]

32. Nagaharu, U.; Nagaharu, N. Genome analysis in Brassica with special reference to the experimental formation of B. napus and peculiar mode of fertilization. Jap. J. Bot. 1935, 7, 389-452.

33. Yang, J.; Liu, D.; Wang, X.; Ji, C.; Cheng, F.; Liu, B.; Hu, Z.; Chen, S.; Pental, D.; Ju, Y.; et al. The genome sequence of allopolyploid Brassica juncea and analysis of differential homoeolog gene expression influencing selection. Nat. Genet. 2016, 48, 1225. Available online: http://www.nature.com/ng/journal/vaop/ncurrent/abs/ng.3657.html\#supplementary-information (accessed on 1 January 2017). [CrossRef] [PubMed] 
34. Oram, R.N.; Kirk, J.T.O.; Veness, P.E.; Hurlstone, C.J.; Edlington, J.P.; Halsall, D.M. Breeding Indian mustard [Brassica juncea (L.) Czern.] for cold-pressed, edible oil production-A review. Aust. J. Agric. Res. 2005, 56, 581-596. [CrossRef]

35. Chèvre, A.M.; Barret, P.; Eber, F.; Dupuy, P.; Brun, H.; Tanguy, X.; Renard, M. Selection of stable Brassica napus-B. juncea recombinant lines resistant to blackleg (Leptosphaeria maculans). 1. Identification of molecular markers, hromosomal and genomic origin of the introgression. Theor. Appl. Genet. 1997, 95, 1104-1111.

36. Bhardwaj, A.R.; Joshi, G.; Kukreja, B.; Malik, V.; Arora, P.; Pandey, R.; Shukla, R.N.; Bankar, K.G.; Katiyar-Agarwal, S.; Goel, S.; et al. Global insights into high temperature and drought stress regulated genes by RNA-Seq in economically important oilseed crop Brassica juncea. BMC Plant Biol. 2015, 1, 1-15. [CrossRef]

37. Van de Wouw, A.P.; Lowe, R.G.; Elliott, C.E.; Dubois, D.J.; Howlett, B.J. An avirulence gene, AvrLmJ1, from the blackleg fungus, Leptosphaeria maculans, confers avirulence to Brassica juncea cultivars. Mol. Plant Pathol. 2014, 15, 523-530. [CrossRef]

38. Potter, T. Development of Brassica juncea as a biodiesel feedstock in low rainfall areas of Australia. In Proceedings of the 13th International Rapeseed Congress, Prague, Crech Republic, 5-9 June 2011.

39. Elliott, V.L.; Marcroft, S.J.; Norton, R.M.; Salisbury, P.A. Reaction of Brassica juncea to Australian isolates of Leptosphaeria maculans and Leptosphaeria biglobosa 'canadensis'. Can. J. Plant Pathol. 2011, 33, 38-48. [CrossRef]

40. Inturrisi, F.; Barbetti, M.; Tirnaz, S.; Patel, D.; Edwards, D.; Batley, J. Molecular characterisation of disease resistance in Brassica juncea-the current status and the way forward. Plant Pathol. 2021, 70, 13-34. [CrossRef]

41. Inturrisi, F.; Bayer, P.E.; Yang, H.; Tirnaz, S.; Edwards, D.; Batley, J. Genome-wide identification and comparative analysis of resistance genes in Brassica juncea. Mol. Breed. 2020, 40, 78. [CrossRef]

42. Cai, C.; Wang, X.; Liu, B.; Wu, J.; Liang, J.; Cui, Y.; Cheng, F.; Wang, X. Brassica rapa genome 2.0: A reference upgrade through sequence re-assembly and gene re-annotation. Mol. Plant 2017, 10, 649-651. [CrossRef]

43. Li, P.; Quan, X.; Jia, G.; Xiao, J.; Cloutier, S.; You, F.M. RGAugury: A pipeline for genome-wide prediction of resistance gene analogs (RGAs) in plants. BMC Genom. 2016, 17, 852. [CrossRef]

44. Holub, E.B. The arms race is ancient history in Arabidopsis, the wildflower. Nat. Rev. Genet. 2001, 2, 516-527. [CrossRef] [PubMed]

45. Alamery, S.; Tirnaz, S.; Bayer, P.; Tollenaere, R.; Chaloub, B.; Edwards, D.; Batley, J. Genome-wide identification and comparative analysis of NBS-LRR resistance genes in Brassica napus. Crop. Pasture Sci. 2018, 69, 72-93. [CrossRef]

46. Wei, Z.; Wang, J.; Yang, S.; Song, Y. Identification and expression analysis of the LRR-RLK gene family in tomato (Solanum lycopersicum) Heinz 1706. Genome 2015, 58, 121-134. [CrossRef]

47. Zhou, T.; Wang, Y.; Chen, J.Q.; Araki, H.; Jing, Z.; Jiang, K.; Shen, J.; Tian, D. Genome-wide identification of NBS genes in japonica rice reveals significant expansion of divergent non-TIR NBS-LRR genes. Mol. Genet. Genom. 2004, 271, 402-415. [CrossRef] [PubMed]

48. Sharma, S.; Kumar, R.; Mendu, V.; Singh, K.; Upadhyay, S.K. Genomic dissection and expression profiling revealed functional divergence in Triticum aestivum leucine rich repeat receptor like kinases (TaLRRKs). Front. Plant Sci. 2016, 7, 1374.

49. Sharma, S.; Pandey, A.K.; Singh, K.; Upadhyay, S.K. Molecular characterization and global expression analysis of lectin receptor kinases in bread wheat (Triticum aestivum). PLoS ONE 2016, 11, e0153925.

50. Agarwal, G.; Garg, V.; Kudapa, H.; Doddamani, D.; Pazhamala, L.T.; Khan, A.W.; Thudi, M.; Lee, S.H.; Varshney, R.K. Genomewide dissection of AP2/ERF and HSP90 gene families in five legumes and expression profiles in chickpea and pigeonpea. Plant Biotechnol. J. 2016, 14, 1563-1577. [CrossRef]

51. Sonnhammer, E.L.; Koonin, E.V. Orthology, paralogy and proposed classification for paralog subtypes. Trends Genet. 2002, 18, 619-620. [CrossRef]

52. Rameneni, J.J.; Lee, Y.; Dhandapani, V.; Yu, X.; Choi, S.R.; Oh, M.H.; Lim, Y.P. Genomic and post-translational modification analysis of leucine-rich-repeat receptor-like kinases in Brassica rapa. PLoS ONE 2015, 10, e0142255. [CrossRef]

53. Kearse, M.; Moir, R.; Wilson, A.; Stones-Havas, S.; Cheung, M.; Sturrock, S.; Buxton, S.; Cooper, A.; Markowitz, S.; Duran, C. Geneious Basic: An integrated and extendable desktop software platform for the organization and analysis of sequence data. Bioinformatics 2012, 28, 1647-1649. [CrossRef]

54. Diévart, A.; Gilbert, N.; Droc, G.; Attard, A.; Gourgues, M.; Guiderdoni, E.; Périn, C. Leucine-rich repeat receptor kinases are sporadically distributed in eukaryotic genomes. BMC Evol. Biol. 2011, 11, 367. [CrossRef] [PubMed]

55. Sun, X.; Wang, G.L. Genome-wide identification, characterization and phylogenetic analysis of the rice LRR-kinases. PLoS ONE 2011, 6, e16079. [CrossRef] [PubMed]

56. Zan, Y.; Ji, Y.; Zhang, Y.; Yang, S.; Song, Y.; Wang, J. Genome-wide identification, characterization and expression analysis of populus leucine-rich repeat receptor-like protein kinase genes. BMC Genom. 2013, 14, 318. [CrossRef]

57. Zhou, F.; Guo, Y.; Qiu, L.J. Genome-wide identification and evolutionary analysis of leucine-rich repeat receptor-like protein kinase genes in soybean. BMC Plant Biol. 2016, 16, 58. [CrossRef] [PubMed]

58. International Wheat Genome Sequencing Consortium (IWGSC). A chromosome-based draft sequence of the hexaploid bread wheat (Triticum aestivum) genome. Science 2014, 345, 1251788. [CrossRef] [PubMed]

59. Schmutz, J.; Cannon, S.B.; Schlueter, J.; Ma, J.; Mitros, T.; Nelson, W.; Hyten, D.L.; Song, Q.; Thelen, J.J.; Cheng, J. Genome sequence of the palaeopolyploid soybean. Nature 2010, 463, 178. [CrossRef]

60. Tirnaz, S.; Bayer, P.; Inturrisi, F.; Zhang, F.; Yang, H.; Dolatabadian, A.; Neik, T.X.; Severn-Ellis, A.; Patel, D.; Ibrahim, M.I.; et al. Resistance gene analogs in the Brassicaceae: Identification, characterization, distribution, and evolution. Plant Physiol. 2020. [CrossRef] 
61. Lohmann, G.V.; Shimoda, Y.; Nielsen, M.W.; Jørgensen, F.G.; Grossmann, C.; Sandal, N.; Sørensen, K.; Thirup, S.; Madsen, L.H.; Tabata, S. Evolution and regulation of the Lotus japonicus LysM receptor gene family. Mol. Plant Microbe Interact. 2010, 23, 510-521. [CrossRef]

62. Arrighi, J.F.; Barre, A.; Amor, B.B.; Bersoult, A.; Soriano, L.C.; Mirabella, R.; de Carvalho-Niebel, F.; Journet, E.P.; Ghérardi, M.; Huguet, T. The Medicago truncatula lysine motif-receptor-like kinase gene family includes NFP and new nodule-expressed genes. Plant Physiol. 2006, 142, 265-279. [CrossRef]

63. Zhang, X.C.; Wu, X.; Findley, S.; Wan, J.; Libault, M.; Nguyen, H.T.; Cannon, S.B.; Stacey, G. Molecular evolution of lysin motif-type receptor-like kinases in plants. Plant Physiol. 2007, 144, 623-636. [CrossRef]

64. Kouzai, Y.; Mochizuki, S.; Nakajima, K.; Desaki, Y.; Hayafune, M.; Miyazaki, H.; Yokotani, N.; Ozawa, K.; Minami, E.; Kaku, $\mathrm{H}$; et al. Targeted gene disruption of OsCERK1 reveals its indispensable role in chitin perception and involvement in the peptidoglycan response and immunity in rice. Mol. Plant Microbe Interact. 2014, 27, 975-982. [CrossRef] [PubMed]

65. Zhang, X.C.; Cannon, S.B.; Stacey, G. Evolutionary genomics of LysM genes in land plants. BMC Evol. Biol. 2009, 9, 183. [CrossRef]

66. Liu, Q.; Chang, S.; Hartman, G.L.; Domier, L.L. Assembly and annotation of a draft genome sequence for Glycine latifolia, a perennial wild relative of soybean. Plant J. Cell Mol. Biol. 2018, 95, 71-85. [CrossRef] [PubMed]

67. Magalhães, D.M.; Scholte, L.L.; Silva, N.V.; Oliveira, G.C.; Zipfel, C.; Takita, M.A.; De Souza, A.A. LRR-RLK family from two Citrus species: Genome-wide identification and evolutionary aspects. BMC Genom. 2016, 17, 623. [CrossRef] [PubMed]

68. Wu, P.; Shao, Z.Q.; Wu, X.Z.; Wang, Q.; Wang, B.; Chen, J.Q.; Hang, Y.Y.; Xue, J.Y. Loss/retention and evolution of NBS-encoding genes upon whole genome triplication of Brassica rapa. Gene 2014, 540, 54-61. [CrossRef]

69. Chen, J.; Piao, Y.; Liu, Y.; Li, X.; Piao, Z. Genome-wide identification and expression analysis of chitinase gene family in Brassica rapa reveals its role in clubroot resistance. Plant Sci. 2018, 270, 257-267. [CrossRef] [PubMed]

70. Friedman, A.R.; Baker, B.J. The evolution of resistance genes in multi-protein plant resistance systems. Curr. Opin. Genet. E Dev. 2007, 17, 493-499.

71. Zhang, J. Evolution by gene duplication: An update. Trends Ecol. E Evol. 2003, 18, $292-298$.

72. Flagel, L.E.; Wendel, J.F. Gene duplication and evolutionary novelty in plants. New Phytol. 2009, 183, 557-564. [CrossRef]

73. Moore, R.C.; Purugganan, M.D. The early stages of duplicate gene evolution. Proc. Natl. Acad. Sci. USA 2003, 100, 15682-15687. [CrossRef]

74. Hwang, S.-G.; Kim, D.S.; Jang, C.S. Comparative analysis of evolutionary dynamics of genes encoding leucine-rich repeat receptor-like kinase between rice and Arabidopsis. Genetica 2011, 139, 1023-1032. [CrossRef]

75. Sun, J.; Li, L.; Wang, P.; Zhang, S.; Wu, J. Genome-wide characterization, evolution, and expression analysis of the leucine-rich repeat receptor-like protein kinase (LRR-RLK) gene family in Rosaceae genomes. BMC Genom. 2017, 18, 763. [CrossRef]

76. Bai, J.; Pennill, L.A.; Ning, J.; Lee, S.W.; Ramalingam, J.; Webb, C.A.; Zhao, B.; Sun, Q.; Nelson, J.C.; Leach, J.E. Diversity in nucleotide binding site-leucine-rich repeat genes in cereals. Genome Res. 2002, 12, 1871-1884. [CrossRef]

77. Liu, S.; Liu, Y.; Yang, X.; Tong, C.; Edwards, D.; Parkin, I.A.; Zhao, M.; Ma, J.; Yu, J.; Huang, S. The Brassica oleracea genome reveals the asymmetrical evolution of polyploid genomes. Nat. Commun. 2014, 5, 3930. [CrossRef] [PubMed]

78. Wang, X.; Wang, H.; Wang, J.; Sun, R.; Wu, J.; Liu, S.; Bai, Y.; Mun, J.-H.; Bancroft, I.; Cheng, F. The genome of the mesopolyploid crop species Brassica rapa. Nat. Genet. 2011, 43, 1035. [CrossRef]

79. Panjabi, P.; Jagannath, A.; Bisht, N.C.; Padmaja, K.L.; Sharma, S.; Gupta, V.; Pradhan, A.K.; Pental, D. Comparative mapping of Brassica juncea and Arabidopsis thaliana using Intron Polymorphism (IP) markers: Homoeologous relationships, diversification and evolution of the A, B and C Brassica genomes. BMC Genom. 2008, 9, 113. [CrossRef] [PubMed]

80. Lysak, M.A.; Koch, M.A.; Pecinka, A.; Schubert, I. Chromosome triplication found across the tribe Brassiceae. Genome Res. 2005, 15, 516-525. [CrossRef] [PubMed]

81. Axelsson, T.; Bowman, C.; Sharpe, A.; Lydiate, D.; Lagercrantz, U. Amphidiploid Brassica juncea contains conserved progenitor genomes. Genome 2000, 43, 679-688. [CrossRef]

82. Cheung, W.; Friesen, L.; Rakow, G.; Seguin-Swartz, G.; Landry, B. A RFLP-based linkage map of mustard [Brassica juncea (L.) Czern. and Coss.]. Theor. Appl. Genet. 1997, 94, 841-851. [CrossRef]

83. Paritosh, K.; Gupta, V.; Yadava, S.K.; Singh, P.; Pradhan, A.K.; Pental, D. RNA-seq based SNPs for mapping in Brassica juncea (AABB): Synteny analysis between the two constituent genomes A (from B. rapa) and B (from B. nigra) shows highly divergent gene block arrangement and unique block fragmentation patterns. BMC Genom. 2014, 15, 396. [CrossRef]

84. Liu, P.L.; Xie, L.L.; Li, P.W.; Mao, J.F.; Liu, H.; Gao, S.M.; Shi, P.H.; Gong, J.Q. Duplication and divergence of leucine-rich repeat receptor-like protein kinase (LRR-RLK) genes in basal angiosperm Amborella trichopoda. Front. Plant Sci. 2016, 7, 1952. [CrossRef] [PubMed]

85. Cannon, S.B.; Zhu, H.; Baumgarten, A.M.; Spangler, R.; May, G.; Cook, D.R.; Young, N.D. Diversity, distribution, and ancient taxonomic relationships within the TIR and non-TIR NBS-LRR resistance gene subfamilies. J. Mol. Evol. 2002, 54, 548-562. [CrossRef] [PubMed]

86. Wan, H.; Yuan, W.; Bo, K.L.; Shen, J.; Pang, X.; Chen, J.F. Genome-wide analysis of NBS-encoding disease resistance genes in Cucumis sativus and phylogenetic study of NBS-encoding genes in Cucurbitaceae crops. BMC Genom. 2013, 14, 109. [CrossRef] [PubMed]

87. Marcussen, T.; Sandve, S.R.; Heier, L.; Spannagl, M.; Pfeifer, M.; Jakobsen, K.S.; Wulff, B.B.; Steuernagel, B.; Mayer, K.F.; Olsen, O.A. Ancient hybridizations among the ancestral genomes of bread wheat. Science 2014, 345, 1250092. [CrossRef] 
88. Petersen, G.; Seberg, O.; Yde, M.; Berthelsen, K. Phylogenetic relationships of Triticum and Aegilops and evidence for the origin of the A, B, and D genomes of common wheat (Triticum aestivum). Mol. Phylogenetics Evol. 2006, 39, 70-82. [CrossRef]

89. Salamini, F.; Özkan, H.; Brandolini, A.; Schäfer-Pregl, R.; Martin, W. Genetics and geography of wild cereal domestication in the Near East. Nat. Rev. Genet. 2002, 3, 429. [CrossRef]

90. Liu, P.L.; Du, L.; Huang, Y.; Gao, S.M.; Yu, M. Origin and diversification of leucine-rich repeat receptor-like protein kinase (LRR-RLK) genes in plants. BMC Evol. Biol. 2017, 17, 47. [CrossRef]

91. Porter, B.W.; Paidi, M.; Ming, R.; Alam, M.; Nishijima, W.T.; Zhu, Y.J. Genome-wide analysis of Carica papaya reveals a small NBS resistance gene family. Mol. Genet. Genom. 2009, 281, 609-626. [CrossRef]

92. Lagercrantz, U. Comparative mapping between Arabidopsis thaliana and Brassica nigra indicates that Brassica genomes have evolved through extensive genome replication accompanied by chromosome fusions and frequent rearrangements. Genetics 1998, 150, 1217-1228.

93. Grant, D.; Cregan, P.; Shoemaker, R.C. Genome organization in dicots: Genome duplication in Arabidopsis and synteny between soybean and Arabidopsis. Proc. Natl. Acad. Sci. USA 2000, 97, 4168-4173. [CrossRef]

94. McCouch, S.R. Genomics and synteny. Plant Physiol. 2001, 125, 152-155. [CrossRef] [PubMed]

95. Tang, H.; Bowers, J.E.; Wang, X.; Ming, R.; Alam, M.; Paterson, A.H. Synteny and collinearity in plant genomes. Science 2008, 320, 486-488. [CrossRef] [PubMed]

96. Frary, A.; Doganlar, S.; Frary, A. Synteny among Solanaceae Genomes. In The Tomato Genome; Causse, M., Giovannoni, J., Bouzayen, M., Zouine, M., Eds.; Springer: Berlin/Heidelberg, Germany, 2016; pp. 217-243.

97. Ling, H.Q.; Ma, B.; Shi, X.; Liu, H.; Dong, L.; Sun, H.; Cao, Y.; Gao, Q.; Zheng, S.; Li, Y. Genome sequence of the progenitor of wheat A subgenome Triticum urartu. Nature 2018, 557, 424-428. [CrossRef] [PubMed]

98. Sharma, A.; Li, X.; Lim, Y.P. Comparative genomics of Brassicaceae crops. Breed. Sci. 2014, 64, 3-13. [CrossRef]

99. Parkin, I. Chasing ghosts: Comparative mapping in the Brassicaceae. In Genetics and Genomics of the Brassicaceae; Schmidt, R., Bancroft, I., Eds.; Springer: Berlin/Heidelberg, Germany, 2011; pp. 153-170.

100. Leister, D. Tandem and segmental gene duplication and recombination in the evolution of plant disease resistance genes. Trends Genet. 2004, 20, 116-122. [CrossRef]

101. Lehti-Shiu, M.D.; Zou, C.; Hanada, K.; Shiu, S.H. Evolutionary history and stress regulation of plant receptor-like kinase/pelle genes. Plant Physiol. 2009, 150, 12-26. [CrossRef]

102. Nobuta, K.; Ashfield, T.; Kim, S.; Innes, R.W. Diversification of non-TIR class NB-LRR genes in relation to whole-genome duplication events in Arabidopsis. Mol. Plant Microbe Interact. 2005, 18, 103-109. [CrossRef]

103. Zeng, L.; Deng, R.; Guo, Z.; Yang, S.; Deng, X. Genome-wide identification and characterization of Glyceraldehyde-3-phosphate dehydrogenase genes family in wheat (Triticum aestivum). BMC Genom. 2016, 17, 240. [CrossRef] 